\title{
Secondary organic aerosol formation and composition from the photo-oxidation of methyl chavicol (estragole)
}

\author{
K. L. Pereira ${ }^{1}$, J. F. Hamilton ${ }^{1}$, A. R. Rickard ${ }^{1,2}$, W. J. Bloss ${ }^{3}$, M. S. Alam ${ }^{3}$, M. Camredon ${ }^{4}$, A. Muñoz ${ }^{5}$, M. Vázquez ${ }^{5}$, \\ E. Borrás ${ }^{5}$, and M. Ródenas ${ }^{5}$ \\ ${ }^{1}$ Wolfson Atmospheric Chemistry Laboratory, Department of Chemistry, University of York, York, UK \\ ${ }^{2}$ National Centre for Atmospheric Science, University of York, York, UK \\ ${ }^{3}$ School of Geography, Earth \& Environmental Sciences, University of Birmingham, Birmingham, UK \\ ${ }^{4}$ LISA, CNRS/INSU - UMR7583, University of Paris-Est Créteil, Paris, France \\ ${ }^{5}$ CEAM-UMH, EUPHORE, Valencia, Spain
}

Correspondence to: J. F. Hamilton (jacqui.hamilton@york.ac.uk)

Received: 4 December 2013 - Published in Atmos. Chem. Phys. Discuss.: 18 December 2013

Revised: 8 April 2014 - Accepted: 22 April 2014 - Published: 3 June 2014

\begin{abstract}
The increasing demand for palm oil for uses in biofuel and food products is leading to rapid expansion of oil palm agriculture. Methyl chavicol (also known as estragole and 1-allyl-4-methoxybenzene) is an oxygenated biogenic volatile organic compound (VOC) that was recently identified as the main floral emission from an oil palm plantation in Malaysian Borneo. The emissions of methyl chavicol observed may impact regional atmospheric chemistry, but little is known of its ability to form secondary organic aerosol (SOA). The photo-oxidation of methyl chavicol was investigated at the European Photoreactor chamber as a part of the atmospheric chemistry of methyl chavicol (ATMECH) project. Aerosol samples were collected using a particle into liquid sampler (PILS) and analysed offline using an extensive range of instruments including; high-performance liquid chromatography mass spectrometry (HPLC-ITMS), high-performance liquid chromatography quadrupole time-of-flight mass spectrometry (HPLCQTOFMS) and Fourier transform ion cyclotron resonance mass spectrometry (FTICR-MS). The SOA yield was determined as 18 and $29 \%$ for an initial VOC mixing ratio of 212 and $460 \mathrm{ppbv}$ (parts per billion by volume) respectively; using a VOC: $\mathrm{NO}_{\mathrm{x}}$ ratio of $\sim 5: 1$. In total, 59 SOA compounds were observed and the structures of 10 compounds have been identified using high-resolution tandem mass spectrometry. The addition of hydroxyl and/or nitro-functional groups to the aromatic ring appears to be an important mechanistic pathway for aerosol formation. This results in the
\end{abstract}

formation of compounds with both low volatility and high $\mathrm{O}: \mathrm{C}$ ratios, where functionalisation rather than fragmentation is mainly observed as a result of the stability of the ring. The SOA species observed can be characterised as semi-volatile to low-volatility oxygenated organic aerosol (SVOOA and LVOOA) components and therefore may be important in aerosol formation and growth.

\section{Introduction}

The atmospheric oxidation of volatile organic compounds (VOCs) in the presence of $\mathrm{NO}_{\mathrm{x}}$ results in the formation of tropospheric ozone and secondary organic aerosol (SOA). Whilst SOA formation is known to have adverse effects on climate and human health (Solomon et al., 2007; Bernstein et al., 2004; Davidson et al., 2005; Pöschl, 2005), the VOC oxidation pathways leading to SOA formation are poorly understood (Hallquist et al., 2009). It has been estimated that as many as $10^{4}-10^{5}$ VOCs have been detected in the atmosphere, all of which may undergo atmospheric oxidation and contribute to SOA formation (Goldstein and Galbally, 2007). Approximately $90 \%$ of all global VOC emissions are from biogenic sources (Guenther et al., 1995). The most abundant biogenic emissions are attributed to isoprene (35-40\%), monoterpenes (11-25\%) and oxygenated VOCs (reactive other VOCs and other VOCs, 20-30\%) (Guenther et al., 1995, 2000). The largest source of biogenic VOC 
emissions are from vegetation; including trees (which account for $\sim 71 \%$ of emissions (Guenther et al., 1995), shrubs and crops, with a small emission source from grasslands and soils (Guenther et al., 1995, 2000; Zimmerman, 1979; Wiedinmyer et al., 2004). Oxygenated VOCs (OVOCs) have received more attention recently due to the advances in instrumentation to detect and quantify these compounds in the ambient atmosphere. Despite this, significant uncertainties still remain in our knowledge of the sources, chemical composition and atmospheric oxidation mechanisms of OVOCs, in particular higher molecular weight species $\left(>\mathrm{C}_{5}\right)$ (Singh et al., 2000; Steiner et al., 2008; Taipale et al., 2012; Schade and Goldstein, 2001; Bouvier-Brown, 2008).

Methyl chavicol $\left(\mathrm{C}_{10} \mathrm{H}_{12} \mathrm{O}\right)$, also known as estragole and 1-allyl-4-methoxybenzene, is a $\mathrm{C}_{10}$ aromatic biogenic OVOC emitted from a variety of pine trees (including ponderosa pine), shrubs (Clausena dunniana, straggly baeckea) and common herbs (basil, fennel, tarragon) (Werker et al., 1994; Simon et al., 1990; Southwell et al., 2003; Mirov, 1961; Bouvier-Brown et al., 2009; De Vincenzi et al., 2000; Barazani et al., 2002; Adams, 2007; Holzinger et al., 2005, 2010). A recent publication identified significant methyl chavicol emissions above the canopy of an oil palm plantation in Malaysian Borneo, with a mean midday flux of $0.81 \mathrm{mg} \mathrm{m}^{-2} \mathrm{~h}^{-1}$ and a mean mixing ratio of $3.0 \mathrm{ppbv}$ (maximum mixing ratio observed $\sim 7.0 \mathrm{ppbv}$ ) (Misztal et al., 2010). Methyl chavicol emissions from oil palm plantations were estimated to result in a global emission of $\sim 0.5 \mathrm{Tg} \mathrm{yr}^{-1}$ (Misztal et al., 2010). There are currently 43 oil palm producing countries, with the majority of oil palm plantations concentrated in Indonesia and Malaysia (FAOSTAT, 2012). In 2011, there were approximately 7.7 Mha (million hectares) of oil palm plantations in Indonesia (USDA, 2013) and 5.0 Mha in Malaysia (MPOB, 2012). The increasing demand for palm oil for uses in food products and biofuels is resulting in the rapid expansion of oil palm agriculture (Fitzherbert et al., 2008). Consequently, methyl chavicol emissions are likely to have a considerable effect on regional chemistry in locations where oil palm plantations are significant. Despite this, there have been few reports in the literature which have investigated the atmospheric fate of methyl chavicol, including gas-phase degradation, SOA formation, composition and yields.

The gas phase products formed from the oxidation of methyl chavicol with hydroxyl radicals $(\cdot \mathrm{OH})$, and ozone $\left(\mathrm{O}_{3}\right)$ has been investigated by Lee et al. (2006a, b), and more recently by Bloss et al. (2012), who reported measurements of the gas-phase reactivity of methyl chavicol with . $\mathrm{OH}$ and $\mathrm{O}_{3}$; and by Gai et al. (2013), who in addition investigated the oxidation of methyl chavicol with $\mathrm{NO}_{3}$. In the study performed by Lee et al. (2006b) the photo-oxidation of methyl chavicol resulted in significant SOA formation (yield $40 \%$ ) and the formation of two abundant, structurally unidentified gas phase compounds, MW (molecular weight, $\left.\mathrm{g} \mathrm{mol}^{-1}\right) 136\left(\mathrm{C}_{8} \mathrm{H}_{8} \mathrm{O}_{2}\right.$, yield $\left.42 \pm 9 \%\right)$ and $\mathrm{MW} 150$
$\left(\mathrm{C}_{9} \mathrm{H}_{10} \mathrm{O}_{2}\right.$, yield $\left.23 \pm 5 \%\right)$, detected using proton transfer reaction mass spectrometry (PTR-MS). Bouvier-Brown et al. (2009) identified MW 136 as 4-methoxybenzaldehyde in the aerosol phase at Blodgett Forest (California, US) and suggested the identification of pinonaldehyde (MW 150) (Holzinger et al., 2005) could be in part attributed to 4methoxybenzene acetaldehyde (MW 150) identified in Lee et al. (2006b). In addition, Cahill et al. (2006) tentatively identified 4-methoxybenzene acetaldehyde in aerosol samples collected in the Sierra Nevada mountains. More recently, Gai et al. (2013) identified a further two abundant gas phase products, MW 122 4-methoxytoluene, and MW 166 4-methoxybenzeneacteic acid, and identified MW 136 and MW 150 as 4-methoxybenzaldehyde and 4-methoxybenzene acetaldehyde, respectively, in support of the literature. To our knowledge, however, the aerosol phase composition and mechanisms of formation from the photo-oxidation of methyl chavicol has largely been unexplored.

The aim of this study is to characterise the SOA oxidation products formed from the photo-oxidation of methyl chavicol and determine their formation mechanisms. Experiments were performed at the European Photoreactor (EUPHORE) chamber in Valencia, Spain, as a part of the atmospheric chemistry of methyl chavicol (ATMECH) project. Aerosol samples were collected using a particle into liquid sampler (PILS). SOA composition was investigated using an extensive range of instruments, including; highperformance liquid chromatography ion trap mass spectrometry (HPLC-ITMS), high-performance liquid chromatography quadrupole time-of-flight mass spectrometry (HPLCQTOFMS) and Fourier transform ion cyclotron resonance mass spectrometry (FTICR-MS).

\section{Materials and methods}

\subsection{Chamber simulation experiments}

Experiments were performed at the European Photoreactor in Valencia, Spain. The EUPHORE facility comprises of two $200 \mathrm{~m}^{3}$ hemispheric reaction chambers made of fluorinated ethyl propylene foil, with housings which may be closed to exclude sunlight. Chamber temperature is near ambient and chamber pressure is maintained at approximately $100 \mathrm{~Pa}$ above ambient. Dry scrubbed air is used within the chamber and two large fans ensure homogenous mixing. Further technical information regarding the chamber design and installation can be found in the literature (Becker, 1996; Klotz et al., 1998; Volkamer et al., 2001; Bloss et al., 2005). A series of experiments were performed during May 2012 and the initial mixing ratios, chamber temperatures and relative humidities are presented in Table 1.

The chamber was cleaned before each experiment by flushing with scrubbed dry air overnight. Methyl chavicol was introduced into the chamber through a heated air stream. 
Table 1. The initial experimental mixing ratios, temperature and relative humidity range for the experiments discussed.

\begin{tabular}{|c|c|c|c|c|c|c|c|c|}
\hline \multirow[t]{2}{*}{ Experiment } & \multirow[t]{2}{*}{ Date } & \multirow[t]{2}{*}{ Experiment description } & \multicolumn{4}{|c|}{ Initial mixing ratio ${ }^{\mathrm{a}}$} & \multicolumn{2}{|c|}{ Experimental range ${ }^{\mathrm{b}}$} \\
\hline & & & $\begin{array}{r}\mathrm{MC}^{\mathrm{c}} \\
{[\mathrm{ppbv}]}\end{array}$ & $\begin{array}{l}\text { NO } \\
{[p p b v]}\end{array}$ & $\begin{array}{l}\mathrm{NO}_{2} \\
{[\mathrm{ppbv}]}\end{array}$ & $\begin{array}{c}\mathrm{O}_{3} \\
{[\mathrm{ppbv}]}\end{array}$ & $\begin{array}{c}\text { Temp } \\
{[\mathrm{K}]}\end{array}$ & $\begin{array}{l}\mathrm{RH} \\
{[\%]}\end{array}$ \\
\hline $\mathrm{MC}_{(0)}$ & 8 May 2012 & Chamber background & 0 & 0.3 & 0.7 & 0 & 294-312 & $0.7-4.7$ \\
\hline $\mathrm{MC}_{\text {low }}$ & 11 May 2012 & Photosmog low concentration & 212 & 38 & 8 & 2 & 298-308 & $0.9-14.7$ \\
\hline $\mathrm{MC}_{\text {high }}$ & 15 May 2012 & Photosmog high concentration & 460 & 92 & 3 & 5 & 297-306 & $2.1-10.7$ \\
\hline
\end{tabular}

${ }^{a}$ On the opening of the chamber covers. ${ }^{b}$ From the opening to the closing of the chamber covers. ${ }^{\mathrm{c}}$ FTIR measurement.

"Classical" photo-oxidation experiments were performed, where no additional $\cdot \mathrm{OH}$ source was added into the chamber. The initial source of $\cdot \mathrm{OH}$ in these experiments was from the photolysis of $\mathrm{HONO}$, formed from the heterogeneous reaction of $\mathrm{NO}_{2}$ and $\mathrm{H}_{2} \mathrm{O}$ on the chamber walls (cf. Sakamaki et al., 1983; Pitts et al., 1984; Svensson et al., 1987; Carter et al., 1981, 1982). An extensive range of monitors were used to measure chamber temperature (temperature sensor, model PT100), pressure (Barometer, model AIR-DB-VOC), humidity (Hygrometer Watz, model Walz-TS2), solar intensity ( $\mathrm{NO}_{2}$ Filter Radiometer), ozone (Monitor Labs, model 9810) and $\mathrm{NO}_{\mathrm{x}}$ (Teledyne API, model NOX_API-T200UP; photolytic converter). PTR-MS (Ionikon Analytik) and Fourier transform infrared (FTIR Nicolet Magna, model 550), coupled to a white-type mirror system with an optical path length of $616 \mathrm{~m}$, were used to monitor methyl chavicol decay and product formation. The chamber dilution rate was calculated by measuring the decay of an inert tracer gas, sulfur hexafluoride $\left(\mathrm{SF}_{6}\right)$, using FTIR: typical pseudo-first-order rate constants of $2 \times 10^{-5} \mathrm{~s}^{-1}$ were obtained, corresponding to a dilution lifetime of around $14 \mathrm{~h}$. The formation and evolution of SOA was measured using a scanning mobility particle sizer (TSI Incorporated, model 3080) consisting of a differential mobility analyser (model 3081) and a condensation particle counter (model 3775).

\subsection{Aerosol sampling and sample preparation}

A Brechtel Manufacturing Inc. (California, USA) model 4002 PILS was used for aerosol collection. The PILS inlet was connected to the chamber outlet using approximately $1.5 \mathrm{~m}$ of $1 / 3^{\prime \prime}$ (inch) stainless steel tubing. Aerosol samples were collected using a $\mathrm{PM}_{1}$ impactor, with an average flow rate of $13 \mathrm{~L} \mathrm{~min}^{-1}$. Acidic, basic and organic gases were removed from the sampled air through the use of denuders, prepared as per the manufacturer's instructions. The wash flow rate was set at $240 \mu \mathrm{L} \mathrm{min}^{-1}$ and consisted of optima LC-MS (liquid chromatography mass spectrometry) grade water (Fisher Scientific, UK). The sample flow rate transferred the aerosol water mixture (optima LC-MS grade water) into sealed vials at a flow rate of $200 \mu \mathrm{L} \mathrm{min}^{-1}$ for $30 \mathrm{~min}$ per sample. Samples were collected before the addition of methyl chavicol or NO into the chamber and continued sampling until after the chamber was closed. After sample collection, punctured vial caps were replaced and securely sealed with parafilm. All vials were wrapped in foil to minimise potential degradation from photolysis and were stored at $-20^{\circ} \mathrm{C}$ until analysis. Collected PILS samples were evaporated to dryness using a V10 vacuum solvent evaporator (Biotage, USA) and redissolved in $300 \mu \mathrm{L}$ of $50: 50$ methanol: water (optima LC-MS grade, Fisher, UK), with the exception of experiment $\mathrm{MC}_{\text {high }}$, which was redissolved in $500 \mu \mathrm{L}$.

The PILS dilutes the sampled aerosol through the transfer of grown particles from the quartz impactor plate into sealed vials, condensation of steam and water uptake during particle growth; see Orsini et al. (2003) for further information. The sample dilution amount is usually determined by spiking a known concentration of lithium fluoride into the sample flow. However, no internal standard was used due to the potential effects on the analytical method (e.g. adduct formation, ion suppression) and SOA composition. PILS samples were evaporated to dryness to eliminate the unknown sample dilution amount. The resuspension of samples into a smaller volume concentrated the aerosol compounds, almost certainly allowing more SOA species to be observed. The resuspension of the PILS samples into 50:50 methanol: water was performed to be more compatible with the HPLC mobile phase and to increase the electrospray ionisation (ESI) efficiency (cf. Kebarle and Verkerk, 2009). The PILS collection efficiency has previously been determined where no appreciable loss has been found for the particle diameter range investigated (30 nm-1 $\mu \mathrm{m})$ (Orsini et al., 2003).

\subsection{HPLC-ITMS}

SOA composition was investigated using an Agilent 1100 series HPLC (Berkshire, UK) coupled to an HTC Plus ion trap mass spectrometer (IT-MS, Bruker Daltonics, Bremen, Germany). A reversed phase Pinnacle C18 $150 \mathrm{~mm} \times 4.6 \mathrm{~mm}$, $5 \mu \mathrm{m}$ particle size column (Thames Resteck, UK) was used. The HPLC mobile phase composition consisted of (A) water (optima LC-MS grade, Fisher, UK) with $0.1 \%$ formic acid (Sigma Aldrich, UK) and (B) methanol (optima LCMS grade, Fisher, UK). Gradient elution was used, starting at 90 (A) and $10 \%$ (B), moving to 0 (A) and $100 \%$ (B) over 
$60 \mathrm{~min}$, returning to the initial starting conditions at $65 \mathrm{~min}$. A 5 min prerun consisting of the starting mobile phase composition was performed before each sample injection. The flow rate was set at $0.6 \mathrm{~mL} \mathrm{~min}^{-1}$ with a sample injection volume of $60 \mu \mathrm{L}$. ESI was used with a dry gas flow rate of $12 \mathrm{~L} \mathrm{~min}^{-1}$, a dry gas temperature of $365^{\circ} \mathrm{C}$ and nebuliser gas pressure of $70 \mathrm{psi}$ (oxygen-free nitrogen, OFN, BOC, $\mathrm{UK})$. The MS was operated in alternating polarity mode, scanning from $\mathrm{m} / \mathrm{z}$ (mass-to-charge ratio) 50 to 600 . Tandem MS was achieved through the automated $\mathrm{MS}^{2}$ function within the Esquire software (Bruker Daltonics, software version 5.2).

\subsection{FTICR-MS}

A solariX Fourier transform ion cyclotron resonance mass spectrometer with a $9.4 \mathrm{~T}$ superconducting magnet (Bruker Daltonics, Coventry, UK) was used and externally calibrated using L-arginine (Sigma Aldrich, UK, purity $98 \%$ ). Samples were introduced into the ESI source through direct infusion using a Hamilton $50 \mu \mathrm{L}$ syringe (Hamilton, Switzerland) at a flow rate of $120 \mu \mathrm{L} \mathrm{min}{ }^{-1}$. Spectra were acquired in both positive and negative ionisation modes over a scan range of $m / z 50-800$. The ESI parameters were set to a dry gas flow rate of $3.7 \mathrm{~L} \mathrm{~min}^{-1}$, dry gas temperature of $220^{\circ} \mathrm{C}$, and a nebuliser gas pressure of 1.2 bar (nitrogen, BOC, UK). Broadband detection mode was used, with 64 spectra averages obtained for each spectrum. Ion accumulation in the ICR (ion cyclotron resonance) cell was set to $0.5 \mathrm{~s}$ with a source accumulation time of $0.002 \mathrm{~s}$. The collision radio frequency (RF) and ion cooler time was set to favour lower masses at $1300 \mathrm{Vpp}$ (volts peak-to-peak) and $0.010 \mathrm{~s}$, respectively. An approximate resolution of 38000 at $\mathrm{m} / \mathrm{z} 400$ was obtained for both ionisation modes. The spectral analysis was performed using DataAnalysis 4.0 software (Bruker Daltonics, Bremen, Germany). Monoisotopic elemental formulae were calculated using the following restrictions: unlimited $\mathrm{C}, \mathrm{H}$ and $\mathrm{O}$ were allowed and up to $3 \mathrm{~N}$ atoms, $\mathrm{O}: \mathrm{C}<3$, $\mathrm{H}: \mathrm{C}>0.5$, DBE (double bond equivalent) $<20$, and in positive mode, $\mathrm{Na}$ and $\mathrm{K}$ adducts were also allowed. The accuracy of the molecular formulae (elemental composition) assignment in shown by the error; where the error equals the difference between the exact and measured mass for the assigned molecular formula. The mass error (also referred to as mass accuracy) is displayed in ppm (parts per million) and is calculated by dividing the mass error by the exact mass for the assigned molecular formula and multiplying by $10^{6}$. The molecular formula score refers to the fit of the theoretical and measured isotopic distribution and abundance for the assigned molecular formula, and is displayed in percentage. The molecular formula score is not calculated for a signal to noise $(S: N)$ ratio below 5 . The combination of a high score and low mass accuracy will result in few potential molecular formula assignments for a compound at a given $m / z$. A compound with an $m / z$ below 300 , with a high score $(100 \%)$ and low mass accuracy $(<5 \mathrm{ppm})$ results in only one potential molecular formula (Kind and Fiehn, 2006).

\subsection{HPLC-QTOFMS}

A Dionex ultimate 3000 HPLC (Thermo Scientific Inc., UK) was coupled with an ultra-high-resolution quadrupole timeof-flight mass spectrometer (HPLC-QTOFMS) (maXis 3G, Bruker Daltonics, Coventry, UK). The HPLC utilised the same reverse phase Pinnacle $\mathrm{C} 18$ column and mobile phase composition as described in the HPLC-ITMS analysis. The gradient elution runtime was shortened, starting at 90 (A) and $10 \%$ (B), moving to 0 (A) and $100 \%$ (B) over $50 \mathrm{~min}$ and returning to the initial starting conditions at $55 \mathrm{~min}$. A 5 min prerun was performed before each sample injection using the starting mobile phase composition. The flow rate was set to $0.6 \mathrm{~mL} \mathrm{~min}^{-1}$ and the column temperature controlled at $20^{\circ} \mathrm{C}$. A user-defined autosampler method was created, drawing $58 \mu \mathrm{L}$ of sample into the sample loop, followed by $2 \mu \mathrm{L}$ of a $10 \mathrm{ppm}$ external standard mix and $20 \mu \mathrm{L}$ of $50: 50$ methanol: water (optima LC-MS grade, Fisher, UK). The HPLC-QTOFMS was externally calibrated using an ESI-L low-concentration tuning mix (Agilent Technologies, UK). ESI was used and the parameters were set to a dry gas flow rate of $10 \mathrm{~L} \mathrm{~min}^{-1}$, dry gas temperature of $350^{\circ} \mathrm{C}$ and a nebuliser pressure of 4 bar (nitrogen, BOC, UK). Tandem mass spectra were acquired for a mass range of $m / z 50-$ 800 using the auto $\mathrm{MS}^{2}$ function within the Compass 1.3 micrOTOF-SR3 software, control version 3.0 (Bruker Daltonics, UK). The three most abundant precursor ions per spectrum were automatically selected by the software and subjected to collision induced dissociation (CID). The collision energy for CID fragmentation was set at $8.0 \mathrm{eV}$ at a collision RF of $800.0 \mathrm{Vpp}$. The spectral analysis was performed using DataAnalysis 4.0 software (Bruker Daltonics, Bremen, Germany). The molecular formula error and score was automatically calculated by the DataAnalysis software using the same methods as described in the FTICR-MS analysis.

\subsection{Standards and calibrations}

A 10 ppm external standard (ES) mix was used to monitor the ITMS detector variation over the course of the sample analysis. The ES mix was also used for the optimisation of the HPLC-QTOFMS method, internal mass calibration and to determine the retention time shift of the SOA compounds due to the shortening of the gradient elution. The ES mix consisted of five compounds, 4-methoxybenzoic acid (Sigma Aldrich, UK, purity 99\%), hexanedioic acid (Sigma Aldrich, UK, purity 99\%), cis-pinonic acid (Sigma Aldrich, UK, purity 99\%), 2-hydroxyhexanoic acid (Acros Organics, Belgium, purity $95 \%$ ) and 2,6-dimethyl-3-nitrophenol (synthesised by University College Cork). These compounds were selected based on their range of retention times, stability, variety of functional groups and ionisation efficiency in both 
positive and negative ionisation modes. Calibrations were performed using the HPLC-ITMS for any structurally identified SOA compounds where standards were commercially available. Calibrations ranged in concentration from 0.02 to $2 \mathrm{ppm}$ and consisted of a minimum of five concentrations, with three replicate measurements.

\section{Results and discussion}

Three experiments carried out as part of the ATMECH campaign are discussed here: (i) $\mathrm{MC}_{(0)}$, a chamber background experiment, where no VOCs or $\mathrm{NO}_{\mathrm{x}}$ were added to the chamber and the chamber housing was opened to expose the chamber to light. None of the methyl chavicol SOA compounds identified were observed in this experiment. (ii) $\mathrm{MC}_{\mathrm{high}}$, a photo-oxidation experiment with high initial mixing ratios of methyl chavicol (460 ppbv) and NO (92 ppbv); and (iii) $\mathrm{MC}_{\text {low }}$, a photo-oxidation experiment with lower mixing ratios of methyl chavicol (212 ppbv) and NO (38 ppbv), with a similar initial $\mathrm{VOC}: \mathrm{NO}_{\mathrm{x}}$ ratio $(\sim 5: 1)$ to $\mathrm{MC}_{\text {high. The }}$ VOC : $\mathrm{NO}_{\mathrm{x}}$ ratio represents the lower $\mathrm{MC}: \mathrm{NO}_{\mathrm{x}}$ ratio of an agro-industrialised oil palm plantation site in northern Borneo (Hewitt et al., 2009; MacKenzie et al., 2011); where the boundary layer $(500-800 \mathrm{~m}) \mathrm{NO}_{\mathrm{x}}$ concentration $(75$ th percentile) was $\sim 0.6 \mathrm{ppbv}$ (Hewitt et al., 2009), with a methyl chavicol abundance of $\sim 3$ ppbv at midday (MacKenzie et al., 2011), corresponding to a $\mathrm{MC}: \mathrm{NO}_{\mathrm{x}}$ ratio of 5. The temporal evolution of $\mathrm{NO}_{\mathrm{x}}, \mathrm{O}_{3}$, methyl chavicol and SOA growth are shown in Fig. 1 and show similar profiles to previous aromatic photo-oxidation experiments, with initiation of aerosol formation occurring when the photo-chemical system enters into a relatively "low NO" state (cf. Rickard et al., 2010). The maximum SOA mass observed, corrected for wall loss and chamber dilution, was 420 and $126 \mu \mathrm{g} \mathrm{m}^{-3}$ in $\mathrm{MC}_{\text {high }}$ and $\mathrm{MC}_{\text {low }}$, respectively. The SOA yield $(Y)$ was calculated using the equation given in Odum et al. (1996), where the amount of aerosol mass formed $\left(\Delta \mathrm{M}_{0}, \mu \mathrm{g} \mathrm{m}^{-3}\right)$ was divided by the amount of methyl chavicol reacted $\left(\Delta \mathrm{MC}, \mu \mathrm{g} \mathrm{m}^{-3}\right.$ ), assuming spherical aerosol shape with a density of $1.4 \mathrm{~g} \mathrm{~cm}^{-3}$. The SOA yield was determined as 18 and $29 \%$ for experiments $\mathrm{MC}_{\text {low }}$ and $\mathrm{MC}_{\mathrm{high}}$, respectively, showing a larger yield at higher initial mixing ratios as seen previously (Song et al., 2005; Odum et al., 1996; Pankow, 1994a, b).

\subsection{SOA composition}

The PILS samples were analysed using a series of complementary analytical techniques. Initially, the HPLC-ITMS was used to screen the PILS samples for SOA species. Any compounds observed in the PILS samples before the introduction of methyl chavicol and NO into the chamber in $\mathrm{MC}_{\text {high }}$ and $\mathrm{MC}_{\text {low }}$ were excluded from further analysis. Compounds which displayed changes in their chromatographic peak areas (and thus concentration) were
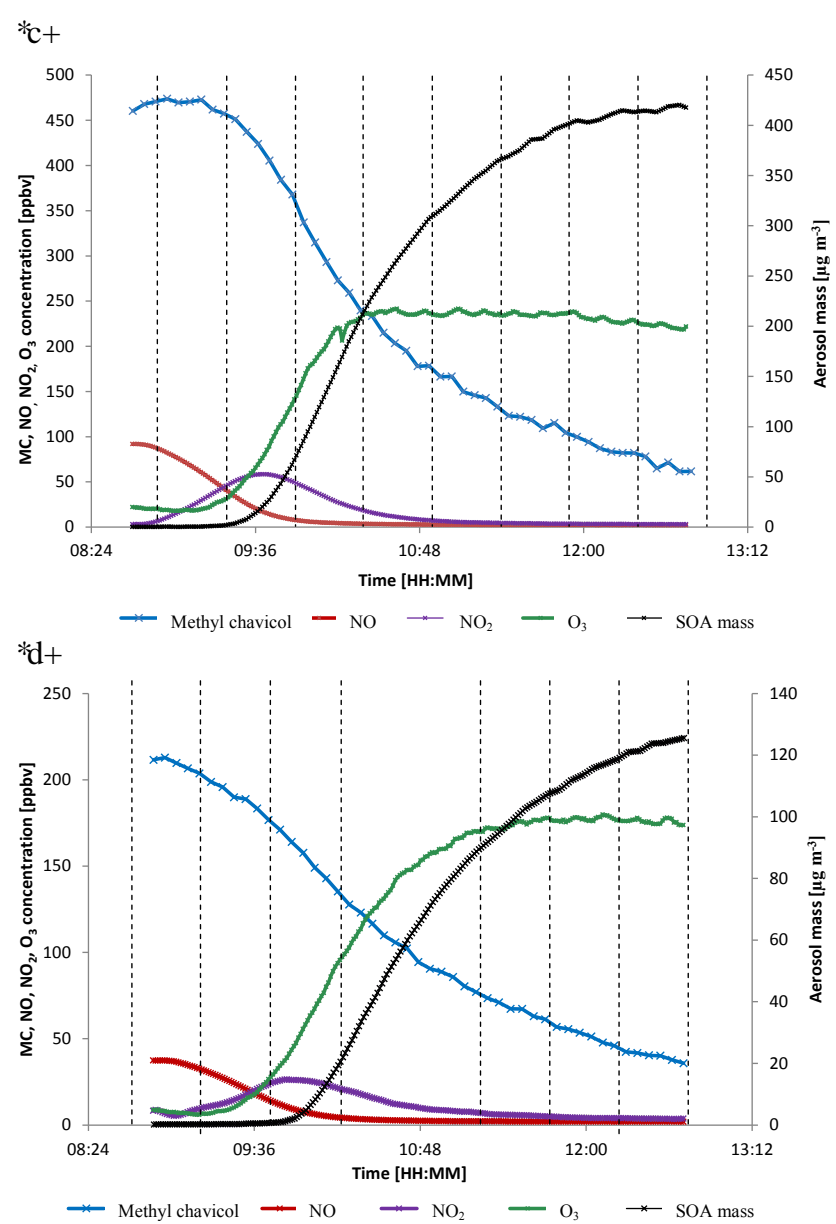

Figure 1. Temporal profiles of methyl chavicol, $\mathrm{O}_{3}, \mathrm{NO}, \mathrm{NO}_{2}$ and SOA mass for $\mathrm{MC}_{\text {low }}$ and $\mathrm{MC}_{\text {high }}$ from the opening to the closing of the chamber housing. (A) $\mathrm{MC}_{\text {high }}$ (opening chamber housing $=08: 42 \mathrm{UTC}$, closing of chamber housing 12:45 UTC), (B) $\mathrm{MC}_{\text {low }}$ (opening chamber housing $=08: 52 \mathrm{UTC}$, closing of chamber housing 12:42 UTC). SOA mass is displayed on the secondary $y$ axis and corrected for wall loss and chamber dilution. Dashed lines display the PILS sample start time. The PILS sample start time 10:43 UTC in $\mathrm{MC}_{\text {low }}$ broke during transport.

investigated further. In the $\mathrm{MC}_{\text {high }}$ experiment, 59 SOA compounds were observed in the PILS samples using HPLCITMS. Of these compounds, 56 were observed with matching retention times and/or fragmentation patterns in the $\mathrm{MC}_{\text {low }}$ experiment. Three compounds at a MW of 214, 226 and $250 \mathrm{~g} \mathrm{~mol}^{-1}$ were not observed in the lower concentration experiment, $\mathrm{MC}_{\mathrm{low}}$. In $\mathrm{MC}_{\text {high }}$, the intensities of these compounds in the HPLC-ITMS analysis were observed just above the limit of detection (defined as $3 \times S: N$ ). The similarity of the oxidation products formed, but the lower initial mixing ratio in $\mathrm{MC}_{\text {low }}$ suggests these compounds were not observed in the $\mathrm{MC}_{\text {low }}$ experiment due to a decrease in the formation yields at lower initial mixing ratios and/or decrease in the gas-particle absorption due to the smaller 
amount of aerosol mass formed (Pankow, 1994a, b; Odum et al., 1996; Kroll and Seinfeld, 2008). In $\mathrm{MC}_{\text {high }}$, fragmentation data was obtained for 56 of the 59 SOA compounds using HPLC-ITMS ${ }^{2}$. In many cases it was not possible to identify the compound structures of the SOA species due to the low mass resolution of the ITMS and lack of commercially available standards. This resulted in the use of the FTICR-MS to aid in the identification of the SOA molecular formulae and compound structures. The use of FTICR-MS significantly aided in compound identification, providing the molecular formulae for 49 of the 59 SOA compounds with an average error of $0.89 \mathrm{ppm}$ for negative ionisation mode and $4.75 \mathrm{ppm}$ for positive ionisation mode. FTICR-MS ${ }^{2}$ could not be performed due to the lack of prior chromatographic separation and the low concentration of the SOA compounds. Instead, HPLC-QTOFMS ${ }^{2}$ was used to obtain high-massresolution compound fragmentation data for the SOA compounds. The HPLC-QTOFMS identified the molecular formulae of 55 of the 59 SOA compounds with an average error of $4.13 \mathrm{ppm}$ for negative ionisation mode and $18.34 \mathrm{ppm}$ for positive ionisation mode. The use of the HPLC-QTOFMS was complementary to the FTICR-MS, allowing the comparison of two high-mass-resolution data sets to determine the molecular formulae of the SOA compounds, as shown in Table 2 and Tables S1 and S2 in the Supplement. The use of prior chromatographic separation with the QTOFMS was advantageous and allowed the molecular formulae of the 10 low concentration SOA compounds not identified using FTICR-MS to be determined. Of the 59 SOA compounds, the FTICR-MS and the HPLC-QTOFMS were in agreement of the molecular formulae for 40 SOA compounds. Only one high-resolution mass spectrometric technique provided the molecular formulae for 14 SOA compounds and for 5 SOA compounds the molecular formulae provided by the HPLCQTOFMS and FTICR-MS were not in agreement. A complete list of the identified SOA species including the molecular formulae identification and associated errors can be found in the Supplement (Tables S1 and S2 in the Supplement).

A Van Krevelen plot of the 59 SOA compounds is shown in Fig. S1 in the Supplement. The average O:C and H:C ratio was determined as 0.46 and 1.37 , respectively. Of the 59 SOA compounds, the structures of 10 have been assigned and are shown in Table 2. The structures of (4methoxyphenyl)acetic acid and 4-methoxybenzoic acid have been confirmed using the retention time and fragmentation patterns of commercially available standards. All other compound structures have been determined from the deprotonated or protonated molecular species fragmentations obtained from the HPLC-ITMS ${ }^{2}$ and HPLC-QTOFMS ${ }^{2}$. Calibrations were performed for 4-methoxybenzoic acid and (4-methoxyphenyl)acetic using the commercially available standards. Detector variation during sample analysis was determined for both compounds by measuring the peak area of 4-methoxybenzoic acid in the $10 \mathrm{ppm}$ ES mix. A $6 \%$ standard deviation is shown and includes a detector variation of $5.14 \%$ (based on four replicate measurements) plus a negligible amount for the PILS collection efficiency (see Sect. 2.2). The concentration of 4-methoxybenzoic acid and (4-methoxyphenyl)acetic acid in $\mathrm{MC}_{\text {high }}$ was determined as $1.26 \pm 0.08$ and $0.41 \pm 0.02 \mu \mathrm{g} \mathrm{m}^{-3}$, representing a total percentage SOA mass of $0.44 \pm 0.03$ and $0.14 \pm 0.01 \%$, respectively. In $\mathrm{MC}_{\text {low }}$, the concentration of 4-methoxybenzoic acid was determined as $0.23 \pm 0.01 \mu \mathrm{g} \mathrm{m}^{-3}$, corresponding to a percentage SOA mass of $0.26 \pm 0.02 \%$. The HPLC-ITMS intensity of (4-methoxyphenyl)acetic acid in the $\mathrm{MC}_{\text {low }}$ experiment was observed below the limit of quantification (defined as $5 \times S: N$ ) and thus the concentration and total percentage SOA mass for this compound could not be determined.

The product ions of two deprotonated molecular species are discussed here as examples to illustrate the methodology used to assign SOA compound structures. Compound 1 with a MW of $243 \mathrm{~g} \mathrm{~mol}^{-1}$ was assigned the molecular formula $\mathrm{C}_{10} \mathrm{H}_{13} \mathrm{NO}_{6}$ with 5 DBE. Compound 1 contains the same number of carbon atoms and one more degree of saturation than the original VOC precursor, methyl chavicol $\left(\mathrm{C}_{10} \mathrm{H}_{12} \mathrm{O}\right)$. In addition, compound 1 was identified in the first PILS sample containing SOA (shortest reaction time; between 41 to $71 \mathrm{~min}$ into the experiment) in $\mathrm{MC}_{\text {high }}$. The similarity of the carbon number, degree of saturation, and the identification of this compound during the initial particle growth, would suggest the structure of compound 1 was similar to that of the precursor, a substituted methoxyphenyl. The product ions of $m / z 242[\mathrm{M}-\mathrm{H}]^{-}$(compound 1) are summarised in Table 3 . Compound 1 was identified as 3-(5-hydroxy-4-methoxy-2-nitrophenyl)propane-1,2-diol using the observed fragments discussed below and shown in Fig. 2. The highest intensity fragment ion at $m / z 224$ is due to the loss of water $\left(\mathrm{H}_{2} \mathrm{O}\right)$ occurring through hydrogen abstraction (Fig. 2a). The base peak loss of $\mathrm{H}_{2} \mathrm{O}$ would suggest the presence of an aliphatic alcohol, most likely terminal. The loss of $\mathrm{H}_{2} \mathrm{O}$ results in an intermolecular rearrangement of the fragment ion, resulting in the formation of a double bond, indicated by the increase in the DBE by 1 . The fragment ion at $m / z 182$ has formed as a result of a subsequent loss of $\mathrm{C}_{2} \mathrm{H}_{2} \mathrm{O}$ from $m / z 224$, which is supported by the decrease in the DBE by 1 for the remaining fragment ion. The fragment ion at $m / z 182$ results from a total loss of $\mathrm{C}_{2} \mathrm{H}_{4} \mathrm{O}_{2}$, suggesting the presence of a second hydroxyl group on the leaving group, most likely on the adjacent carbon to the first alcohol group (Fig. 2b). The fragment ion at $\mathrm{m} / \mathrm{z} 167$ has formed as a result of an odd electron cleavage (OE), resulting in the formation of $\left[\mathrm{C}_{7} \mathrm{H}_{5} \mathrm{NO}_{4}\right]^{--}$and the loss of $\left[\mathrm{C}_{3} \mathrm{H}_{7} \mathrm{O}_{2}\right]$ (Fig. 2c). OE cleavages are unusual in CID and are often associated with resonance stabilised ring structures and nitrogen-containing functional groups (Fu et al., 2006; Holčapek et al., 2007, 2010; Hayen et al., 2002).

Assuming the remaining deprotonated radical fragment ion at $m / z 167\left[\mathrm{C}_{7} \mathrm{H}_{5} \mathrm{NO}_{4}\right]^{-}$is a substituted methoxyphenyl, the subtraction of the methoxy $\left[\mathrm{OCH}_{3}\right]$ and aromatic 
约

는

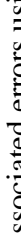

ฮี

胥

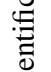

疍

$\sum$

范

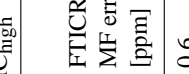

言豆突

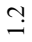

$\stackrel{\infty}{+}$

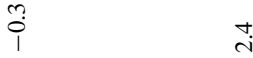

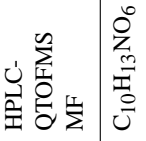

兽

0
0
1
0
0

$\begin{array}{ll}+ & 0 \\ 0 & 0 \\ 0 & 0 \\ 0 & 0\end{array}$

$\stackrel{\infty}{\circ}$

$\stackrel{\infty}{\circ} \quad \stackrel{0}{0}$

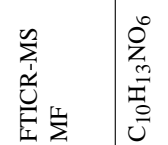

ᄋ

$\begin{array}{ll}0 & 0 \\ 0 & 0 \\ 0 & 0 \\ 0 & 0 \\ 0 & 0\end{array}$



$\underline{\vec{\sigma}}$

ฮิ่

空

$\approx \quad$ i

อับ

$\stackrel{\circ}{\circ}$

$\stackrel{+}{\Phi}$

$\stackrel{\infty}{\infty}$
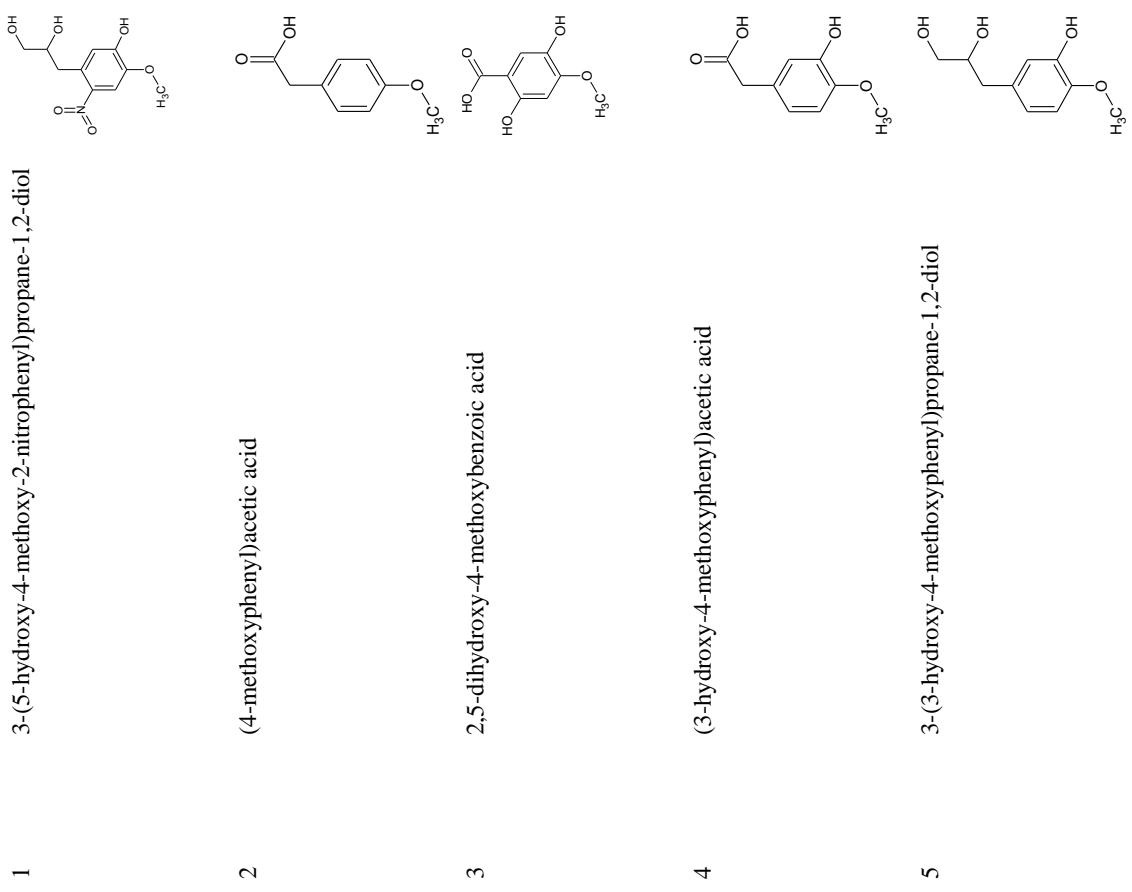

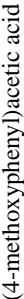

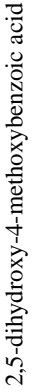

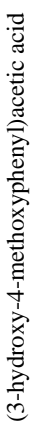

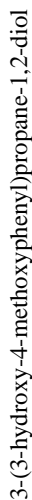

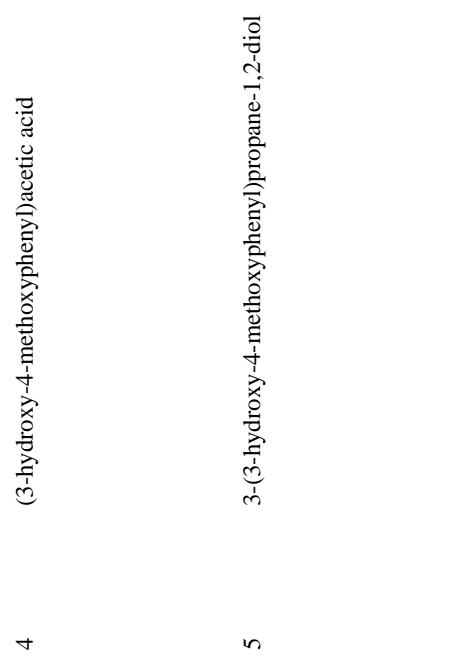




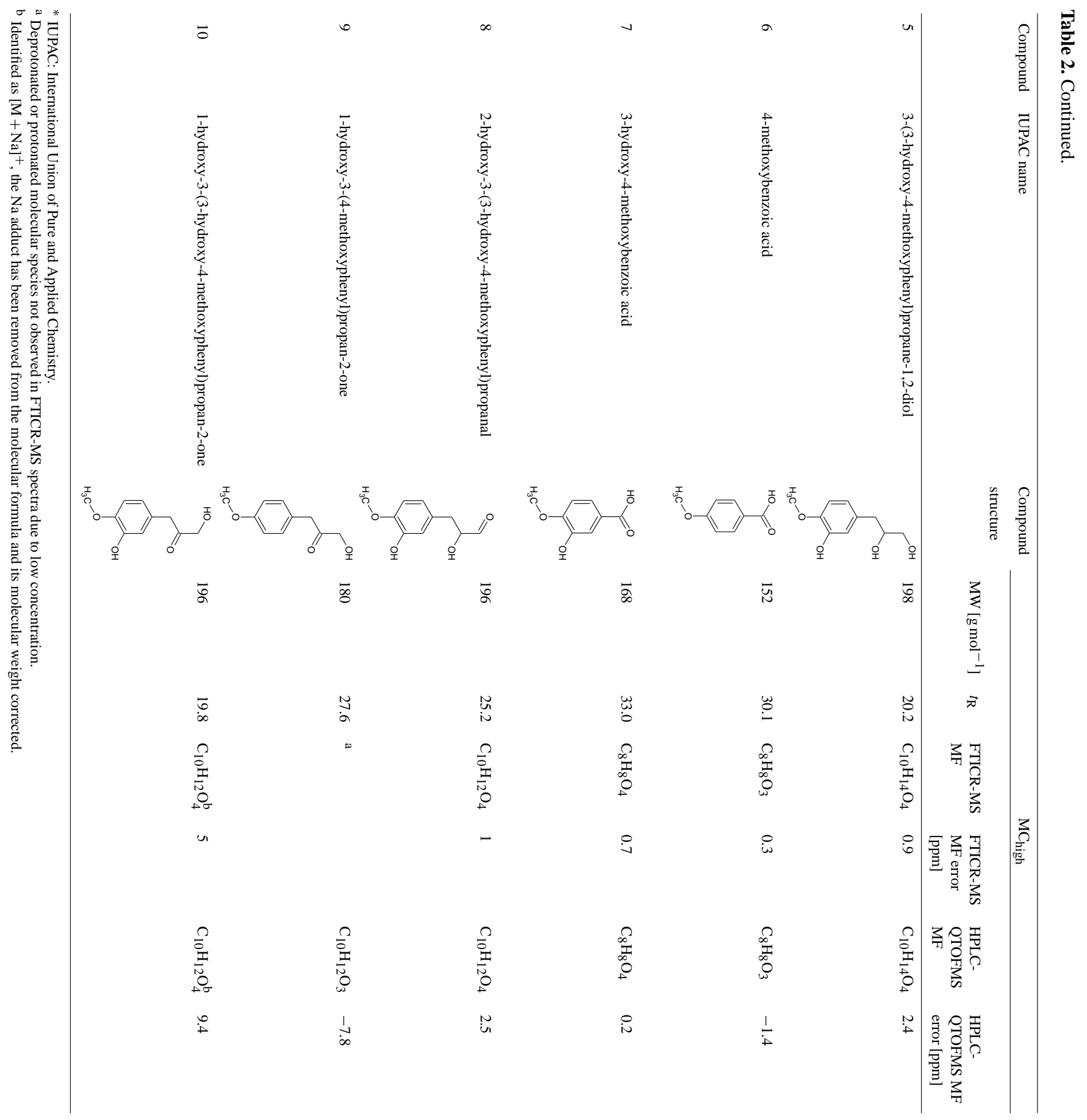


Table 3. Deprotonated molecular species fragmentation for compound 1 , obtained from the use of the HPLC-ITMS ${ }^{2}$ and the HPLC-QTOFMS ${ }^{2}$.

\begin{tabular}{|c|c|c|c|c|c|c|c|c|c|c|}
\hline MF & {$[\mathrm{M}-\mathrm{H}]^{-}$} & DBE & $\begin{array}{l}\text { Fragment } \\
\text { ion }[m / z]\end{array}$ & $\begin{array}{c}\text { Fragment ion } \\
\text { MF }\end{array}$ & DBE & Loss [Da] & $\begin{array}{c}\text { Electron } \\
\text { fragmentation }\end{array}$ & $\begin{array}{l}\text { Fragment } \\
\text { ion MF } \\
\text { error } \\
{[\mathrm{ppm}]}\end{array}$ & $\begin{array}{c}\text { MF } \\
\text { Score } \\
{[\%]}\end{array}$ & $\begin{array}{l}\text { Fragmentation } \\
\text { shown }\end{array}$ \\
\hline $\mathrm{C}_{10} \mathrm{H}_{13} \mathrm{NO}_{6}$ & 242 & 5 & $\begin{array}{l}224 \\
182 \\
167 \\
137\end{array}$ & $\begin{array}{l}\mathbf{C}_{\mathbf{1 0}} \mathrm{H}_{\mathbf{1 0}} \mathbf{N O}_{\mathbf{5}} \\
\mathrm{C}_{8} \mathrm{H}_{8} \mathrm{NO}_{4} \\
\mathrm{C}_{7} \mathrm{H}_{5} \mathrm{NO}_{4} \\
\mathrm{C}_{7} \mathrm{H}_{5} \mathrm{O}_{3}\end{array}$ & $\begin{array}{l}6 \\
5 \\
5^{*} \\
4^{* *}\end{array}$ & $\begin{array}{l}\mathbf{1 8} \\
(18+42)=60 \\
(18+57)=75 \\
105\end{array}$ & $\begin{array}{l}\text { EE } \\
\text { EE } \\
\text { OE } \\
\text { OE }\end{array}$ & $\begin{array}{r}-2.1 \\
-1 \\
8.8 \\
-19.2\end{array}$ & $\begin{array}{l}\mathbf{1 0 0} \\
100 \\
100 \\
100\end{array}$ & $\begin{array}{l}\text { Fig. 2a } \\
\text { Fig. 2b } \\
\text { Fig. 2c } \\
\text { Fig. 2c }\end{array}$ \\
\hline
\end{tabular}

The highest intensity fragment ion is shown in bold. DBE: double bond equivalent. Electron fragmentation, EE: even electron, OE: odd electron. MF: molecular formula.

* DBE was manually calculated as automated DBE calculation is incorrect for radical fragment ions (DBE = 5.5-0.5 (for one "hydrogen atom deficiency") $=5$ ), see

Pellegrin (1983) for the calculation of DBE and DBE correction for radical ions). ${ }^{* *}$ DBE manually calculated (DBE $=5-1$ (for two "hydrogen atom deficiencies") $\left.=4\right)$.

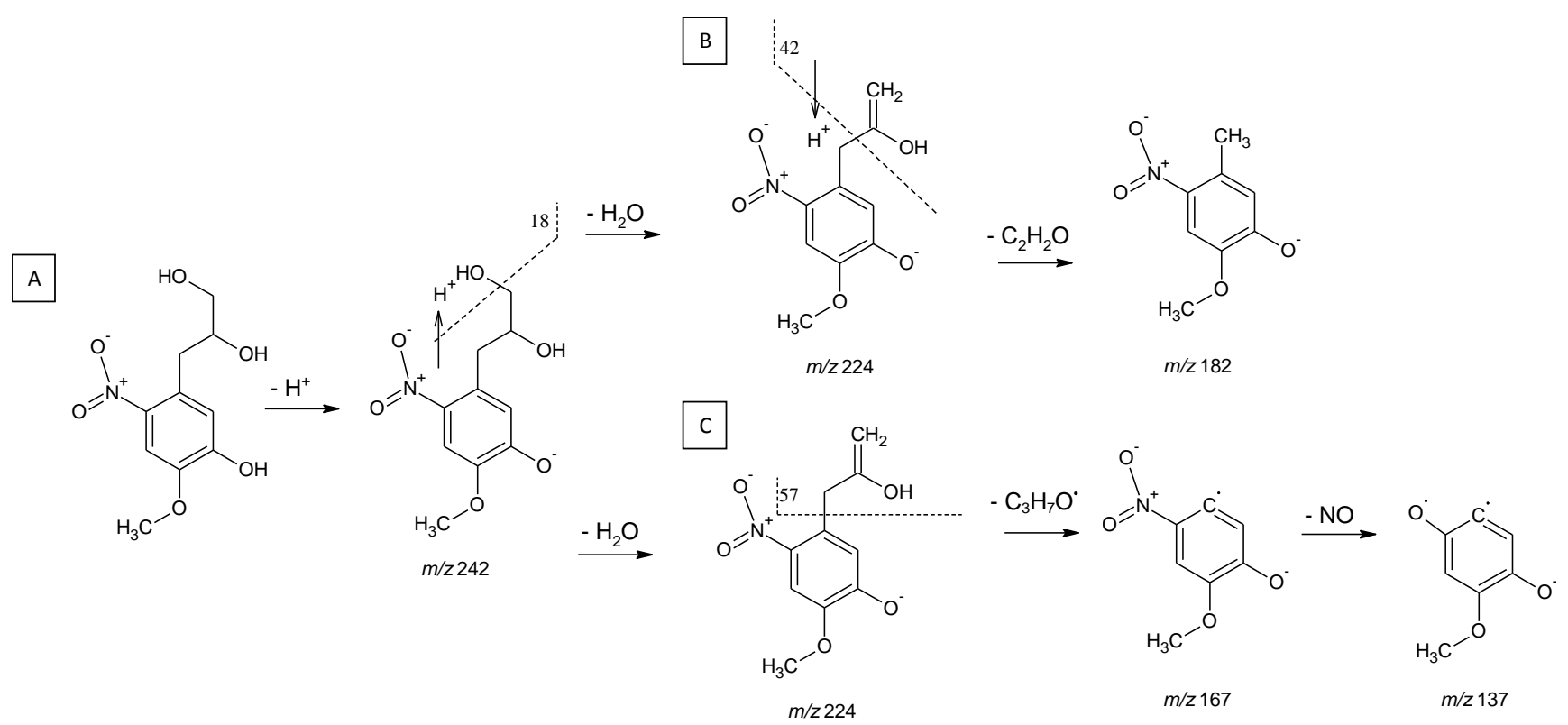

Figure 2. Proposed deprotonated molecular species fragmentation for compound 1 in negative ionisation mode. Dashed lines indicate the location of fragmentation.

$\left[\mathrm{C}_{6} \mathrm{H}_{2}\right]^{-}$group from the molecular formula would leave $\mathrm{N}_{1} \mathrm{O}_{3}$ unaccounted for. This suggests either a nitrate group $\left(\mathrm{R}-\mathrm{ONO}_{2}\right)$, or a hydroxyl $(\mathrm{R}-\mathrm{OH})$ and a nitro $\left(\mathrm{R}-\mathrm{NO}_{2}\right)$ group are attached to the ring. The presence of a nitrate group on the ring is likely to result in the loss of $\mathrm{NO}_{2}$ or $\mathrm{ONO}_{2}$ from the fragmentation of the carbon-oxygen or oxygennitrogen bond during CID (Zhao and Yinon, 2002; Holčapek et al., 2010). Furthermore, the lability of the nitrate group often results in spontaneous fragmentation in the softest ESI conditions, resulting in the fragment ions $\mathrm{ONO}_{2}$ and $\mathrm{NO}_{2}$ at $m / z 63$ and $m / z 47$, respectively (Holčapek et al., 2010; Yinon et al., 1997). However, no fragment ion at $m / z 63$ for $\mathrm{ONO}_{2}$ was observed. A peak at $m / z 137$ (intensity $1.33 \%$ ) was observed and was attributed to $\left[\mathrm{C}_{7} \mathrm{H}_{5} \mathrm{O}_{3}\right]^{-}$, the loss of $\mathrm{NO}$ from the fragment ion at $m / z, 167\left[\mathrm{C}_{7} \mathrm{H}_{5} \mathrm{NO}_{4}\right]^{--}$ (Fig. 2c). The loss of NO is typical for nitro functional groups in negative ionisation mode using CID (Holčapek et al., 2010; Fu et al., 2006; Schmidt et al., 2006; Yinon et al., 1997). The rearrangement of bonds from $\mathrm{R}-\mathrm{NO}_{2}$ to R-ONO results in the loss of NO (Schmidt et al., 2006). Nitro functional groups usually result in the loss of $\mathrm{NO}$ and $\mathrm{NO}_{2}$. However, the loss of only NO has been observed for some compounds containing a nitro functional group and has previously been suggested to be the result of an electron-donating substituent in the para position to the nitro group, enhancing the loss of NO by resonance stabilisation (Bursey and McLafferty, 1966; Bursey, 1969).

The location of phenyl substitutions has proved to be difficult to determine using CID due to the lack of ring fragmentation as a result of resonance stabilisation. In addition, the $\mathrm{N}$-containing compounds that were observed to undergo ring fragmentation exhibited complex rearrangements making the identification of these compound structures a difficult task. However, the most likely locations of phenyl substitutions 
Table 4. Deprotonated molecular species fragmentation for compound 5, obtained from the use of the HPLC-ITMS ${ }^{2}$ and the HPLC-QTOFMS ${ }^{2}$.

\begin{tabular}{|c|c|c|c|c|c|c|c|c|c|c|}
\hline MF & {$[\mathrm{M}-\mathrm{H}]^{-}$} & DBE & $\begin{array}{l}\text { Fragment } \\
\text { ion }[m / z]\end{array}$ & $\begin{array}{l}\text { Fragment } \\
\text { ion MF }\end{array}$ & DBE & Loss [Da] & $\begin{array}{c}\text { Electron } \\
\text { fragmentation }\end{array}$ & $\begin{array}{c}\text { Fragment } \\
\text { ion MF } \\
\text { error } \\
{[\mathrm{ppm}]}\end{array}$ & $\begin{array}{c}\mathrm{MF} \\
\text { Score } \\
{[\%]}\end{array}$ & $\begin{array}{c}\text { Fragmentation } \\
\text { shown }\end{array}$ \\
\hline $\mathrm{C}_{10} \mathrm{H}_{14} \mathrm{O}_{4}$ & 197 & 4 & $\begin{array}{l}\mathbf{1 7 9} \\
137 \\
123\end{array}$ & $\begin{array}{l}\mathbf{C}_{\mathbf{1 0}} \mathbf{H}_{\mathbf{1 1}} \mathbf{O}_{\mathbf{3}} \\
\mathrm{C}_{8} \mathrm{H}_{9} \mathrm{O}_{2} \\
\mathrm{C}_{7} \mathrm{H}_{7} \mathrm{O}_{2}\end{array}$ & $\begin{array}{l}5 \\
4 \\
4\end{array}$ & $\begin{array}{l}\mathbf{1 8} \\
(18+42)=60 \\
74\end{array}$ & $\begin{array}{l}\text { EE } \\
\text { EE } \\
\text { EE }\end{array}$ & $\begin{array}{r}-\mathbf{1 9 . 3} \\
-0.5 \\
-3.4\end{array}$ & $\begin{array}{l}100 \\
100 \\
100\end{array}$ & $\begin{array}{l}\text { Fig. 3a } \\
\text { Fig. 3b } \\
\text { Fig. 3c }\end{array}$ \\
\hline
\end{tabular}

The highest intensity fragment ion is shown in bold. DBE: double bond equivalent. Electron fragmentation, EE: even electron. MF: molecular formula.

can be identified by considering the formation mechanisms of these compounds in the gas phase (Ziemann and Atkinson, 2012; Calvert et al., 2002). Methyl chavicol has two phenyl substituents, a methoxy group and an hydrocarbon (HC) chain, both of which are ortho, para directing (March, 1992). The stronger activating group of the two phenyl substituents, the methoxy group, will determine the most energetically favoured and resonance stabilised position of an addition to the ring (March, 1992). The para position to the methoxy group is occupied by the HC chain and therefore the initial oxidation of a hydroxyl radical to the ring of methyl chavicol would be most energetically favoured at the ortho position to the methoxy group (Ziemann and Atkinson, 2012). The location of the nitro group on the ring is more difficult to assign. Assuming the hydroxyl radical is already attached to the ring, the most strongly activating group would now be the hydroxyl group, which is also ortho, para directing (March, 1992). The ortho position to the hydroxyl group is more sterically hindered by the adjacent $\mathrm{HC}$ chain and hydroxyl group, compared to the para position, which is only sterically hindered by the $\mathrm{HC}$ chain. It is therefore suggested that the nitro group is located in the para position to the hydroxyl group. The suggested location of the nitro and hydroxyl group on the ring is also supported by the mechanism suggested in Bursey (1969) and Bursey and McLafferty (1966), where the loss of only NO is observed for a nitro functional group during CID when an activating group is located in the para position to the nitro group.

Compound 5, with a MW of $198 \mathrm{~g} \mathrm{~mol}^{-1}$, was assigned the molecular formula $\mathrm{C}_{10} \mathrm{H}_{14} \mathrm{O}_{4}$ with $4 \mathrm{DBE}$. The product ions of $m / z 197[\mathrm{M}-\mathrm{H}]^{-}$(compound 5) are summarised in Table 4. Compound 5 was identified as 3-(3-hydroxy-4methoxyphenyl)propane-1,2-diol from the product ions discussed here and shown in Fig. 3. Both compounds 1 and 5 exhibit similar $\mathrm{HC}$ chain fragmentation, with the loss of $18 \mathrm{Da}\left(\mathrm{H}_{2} \mathrm{O}\right)$ and $42 \mathrm{Da}\left(\mathrm{C}_{2} \mathrm{H}_{2} \mathrm{O}_{2}\right)$ (Fig. 3a, b). The product ion $\left[\mathrm{C}_{7} \mathrm{H}_{7} \mathrm{O}_{2}\right]^{-}$at $m / z, 123$ resulted from an even electron (EE) loss of $\mathrm{C}_{3} \mathrm{H}_{6} \mathrm{O}_{2}$, unlike the $\mathrm{OE}$ loss of $\left[\mathrm{C}_{3} \mathrm{H}_{7} \mathrm{O}_{2}\right]$. observed for compound 1 (Fig. 3c). Compound 5 does not have a nitro group present on the ring and as a result the resonance stabilisation of the aromatic ring is lower than in compound 1 . The decrease in resonance stabilisation results in an EE cleavage and the abstraction of a hydrogen from the leaving group to the aromatic ring. Hydrogen abstraction from the loss group results in an intermolecular rearrangement and the loss of $\mathrm{C}_{3} \mathrm{H}_{6} \mathrm{O}_{2}$. Therefore, the same $\mathrm{HC}$ chain has been suggested for both compounds 1 and 5. Assuming a methoxyphenyl substructure, the deprotonated product ion would leave $\left[\mathrm{C}_{6} \mathrm{H}_{3} \mathrm{O}\right]^{-}$from product ion $\left[\mathrm{C}_{7} \mathrm{H}_{7} \mathrm{O}_{2}\right]^{-}$at $\mathrm{m} / z 123$, suggesting a hydroxyl group is attached to the aromatic ring.

\subsection{Mechanism of formation}

A proposed mechanism for the formation of compounds 1 , 5, 8, 9 and 10 is shown in Fig. 4a and b. The formation of these compounds can be rationalised as the products of methyl chavicol oxidation by considering typical gas phase oxidation mechanisms (Ziemann and Atkinson, 2012; Calvert et al., 2002). The reaction rate constants of methyl chavicol with $\cdot \mathrm{OH}$ and $\mathrm{O}_{3}$ have previously been determined as $5.20 \pm 0.78 \times 10^{-11}$ and $1.03 \pm 0.23 \times 10^{-17} \mathrm{~cm}^{3}$ molecule ${ }^{-1} \mathrm{~s}^{-1}$, respectively (Gai et al., 2013). The proportion of methyl chavicol reacting with $\cdot \mathrm{OH}$ and $\mathrm{O}_{3}$ during $\mathrm{MC}_{\text {low }}$ and $\mathrm{MC}_{\text {high }}$ is shown in Figs. S2 and S3 in the Supplement, respectively; where throughout both experiments the reaction of methyl chavicol with $\cdot \mathrm{OH}$ is observed to dominate over the reaction with $\mathrm{O}_{3}$. The initial oxidation of methyl chavicol will proceed mainly through the .OH radical addition mechanism (Atkinson, 1997a; Calvert et al., 2002; Ziemann and Atkinson, 2012) and can attack the ring and/or the $\mathrm{HC}$ chain. $\mathrm{OH}$ radical addition can occur on either carbon of the double bond of the HC chain, resulting in the formation of primary and secondary $\beta$-hydroxyalkyl radicals, with the secondary $\beta$-hydroxyalkyl radical pathway being the most favoured (approximately $85 \%$ using the Peeters et al., 2007, $\cdot \mathrm{OH}$ addition structure-activity relationship) (Atkinson, 2000, 1997a; Cvetanovic, 1976). The resulting $\beta$-hydroxyalkyl radicals react predominantly with $\mathrm{O}_{2}$ to form $\beta$-hydroxyperoxy radicals. The high concentration of $\mathrm{NO}$ at the beginning of $\mathrm{MC}_{\text {high }}$ and $\mathrm{MC}_{\text {low }}$ will result in the conversion of $\mathrm{NO}$ to $\mathrm{NO}_{2}$ (leading to $\mathrm{O}_{3}$ formation) and the formation of $\beta$-hydroxyalkoxy radicals as the major pathway. $\beta$-hydroxyalkoxy radicals can react with $\mathrm{O}_{2}$, 


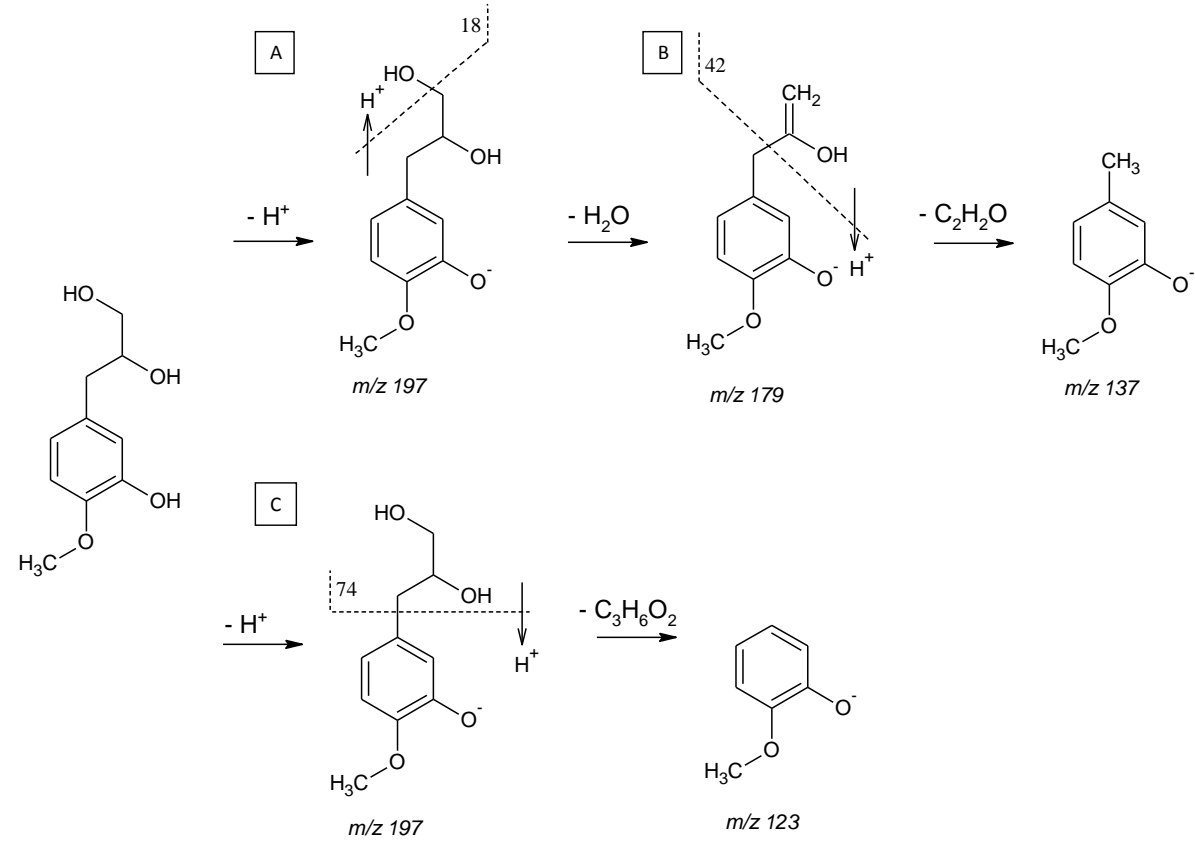

Figure 3. Proposed deprotonated molecular species fragmentation for compound 5 in negative ionisation mode. Dashed lines indicate the location of fragmentation.

decompose or isomerise. Decomposition and isomerisation are expected to be the dominant pathways, with the exception of the $\mathrm{HOCH}_{2} \mathrm{CH}_{2} \mathrm{O}$. radical (from ethene $+\cdot \mathrm{OH}$ ), for which decomposition and reaction with $\mathrm{O}_{2}$ can be competitive (Atkinson, 1997a, b; Fuchs et al., 2011).

For both types of $\beta$-hydroxyalkoxy radicals formed, decomposition followed by rapid reaction with $\mathrm{O}_{2}$ leads to the formation of formaldehyde, $\mathrm{HO}_{2}$ and (4methoxyphenyl)acetaldehyde (Atkinson, 1997a; Orlando et al., 2003). Isomerisation through a $1,5-\mathrm{H}$ atom shift from the aromatic ring to the $\mathrm{HC}$ chain is suggested to be of minor importance due to the resonance stability of the ring. The reaction with $\mathrm{O}_{2}$ (minor pathway) would result in the loss of $\mathrm{HO}_{2}$ and the formation of the observed first generation compound, 1-hydroxy-3-(4-methoxyphenyl)propan-2-one (compound 9), Fig. 4a (A). Further oxidation of this compound through the addition of a hydroxyl radical to the ring results in the formation of 1-hydroxy-3-(3-hydroxy-4methoxyphenyl)propan-2-one (compound 10), Fig. 4a (B). As discussed in the previous section, the initial hydroxyl addition to the ring will occur at the ortho position to the methoxy group, the position which is most energetically favoured and resonance stabilised. Compound 8, 2-hydroxy3-(3-hydroxy-4-methoxyphenyl)propanal, is also suggested to be a second-generation compound which has formed through the oxidation of the primary $\beta$-hydroxyalkoxy radicals with $\mathrm{O}_{2}$ (the less favoured pathway) and has been further oxidised by the addition of a hydroxyl radical to the ring, Fig. 4b (A).
As a relatively "low $\mathrm{NO}_{\mathrm{x}}$ state" is entered in $\mathrm{MC}_{\text {high }}$ and $\mathrm{MC}_{\text {low }}$ the $\mathrm{RO}_{2}+\mathrm{RO}_{2}$ or $\mathrm{HO}_{2}$ reaction will begin to dominate over the competing reaction with NO (Atkinson, 1997a; Stockwell et al., 1990). The cross/self reaction of $\beta$-hydroxyperoxy radicals will proceed mainly through two pathways: the radical pathway and non-radical pathway (hydrogen abstraction), with the radical pathway accounting for approximately $30-80 \%$ of the $\mathrm{RO}_{2}+\mathrm{RO}_{2}$ reaction (Atkinson, 1997a; Madronich and Calvert, 1990). The radical pathway (major pathway) will result in the formation of $\beta$-hydroxyalkoxy radicals with the loss of $\mathrm{O}_{2}$. The $\beta$ hydroxyalkoxy radicals can then undergo oxidation through the same mechanisms as discussed above, resulting in a secondary pathway for the formation of compounds 8,9 and 10, Fig. 4b (B), (C) and (D), respectively. A third minor pathway to the formation of compounds 8,9 and 10 can also occur through the $\mathrm{RO}_{2}+\mathrm{RO}_{2}$ non radical pathway; where one peroxy radical abstracts a hydrogen atom from another peroxy radical, resulting in the formation of an alcohol and carbonyl, respectively, with the loss of $\mathrm{O}_{2}$ (Madronich and Calvert, 1990; Howard and Ingold, 1968). The hydrogen atom is abstracted from the carbon bonded to the peroxy radical, thus the abstraction of a hydrogen atom from a secondary $\beta$-hydroxyperoxy radical will result in the formation of 1-hydroxy-3-(4-methoxyphenyl)propan-2-one (compound 9), Fig. 4a (E). The further oxidation of this compound though the reaction with $\cdot \mathrm{OH}$ will result in the formation of 1-hydroxy-3-(3-hydroxy-4-methoxyphenyl)propan-2-one (compound 10), Fig. 4a (F). Moreover, the abstraction of a hydrogen from a primary $\beta$-hydroxyperoxy radical followed 


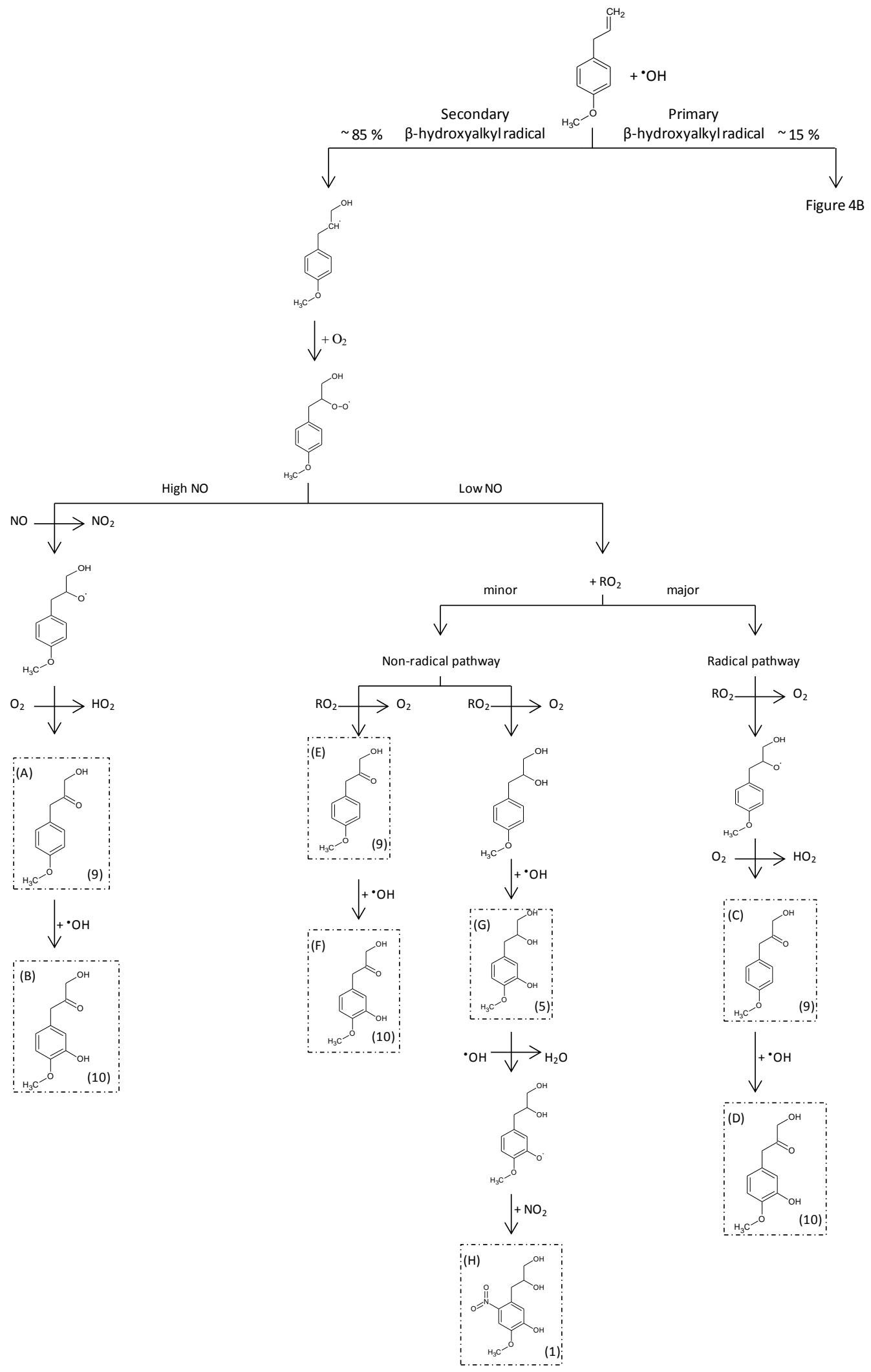

Figure 4. (a) Mechanism of formation for the identified SOA compounds through the secondary $\beta$-hydroxyalkyl radical pathway, compounds 1, 5, 9 and 10, shown in brackets, refer to Table 2 for compound identification. See text for the explanation of the mechanism, letters refer to the explanation in the text. Boxes highlight identified SOA compounds. 


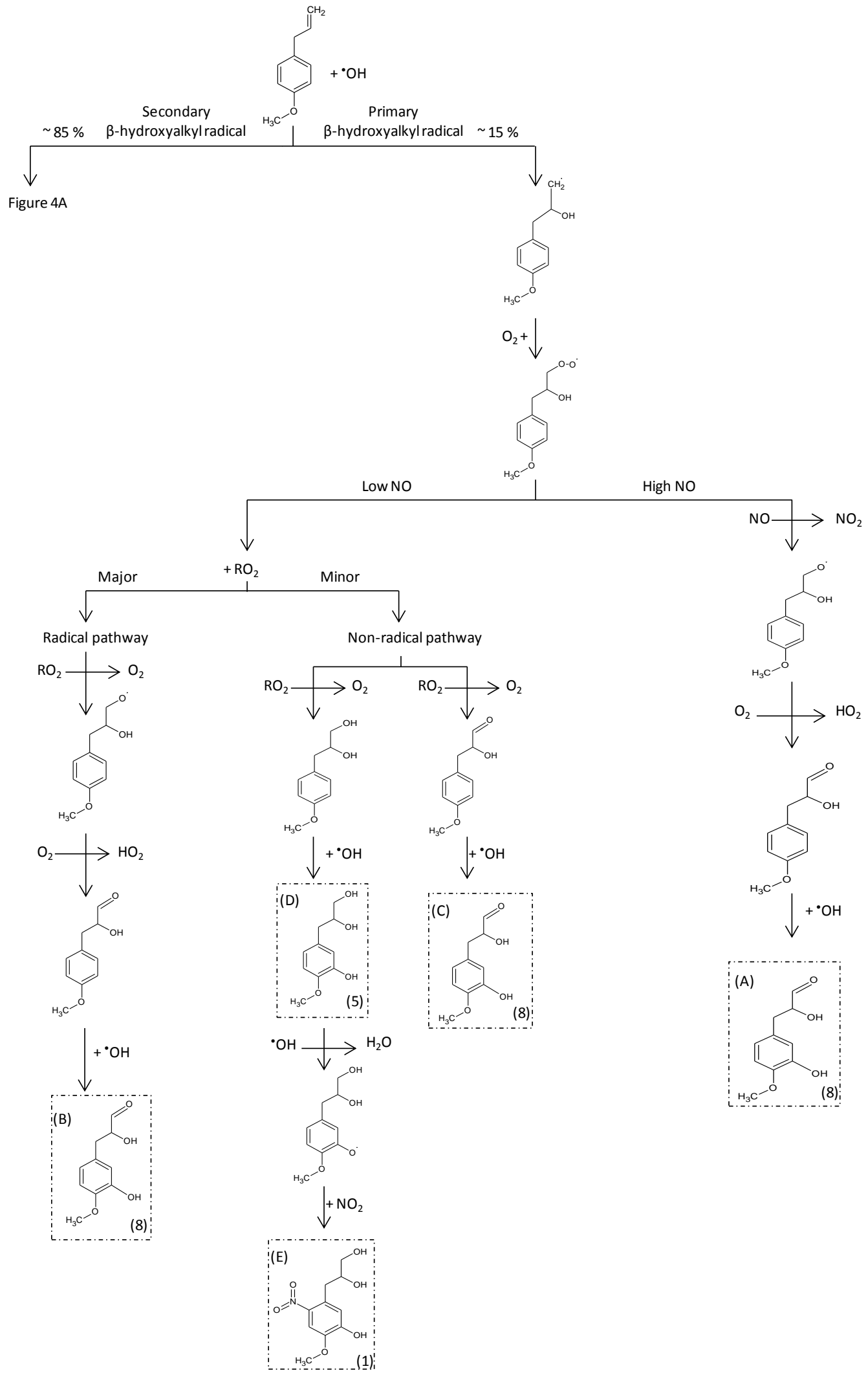

Figure 4. (b) Mechanism of formation for the identified SOA compounds through the primary $\beta$-hydroxyalkyl radical pathway, compounds 1 , 5 and 8, shown in brackets, refer to Table 2 for compound identification. See text for the explanation of the mechanism, letters refer to the explanation in the text. Boxes highlight identified SOA compounds. 
by the further oxidation of an $\cdot \mathrm{OH}$ radical to the ring, will result in the formation of 2-hydroxy-3-(3-hydroxy-4methoxyphenyl)propanal (compound 8), Fig. 4b (C).

The formation of the diol on the HC chain of compound 1 (3-(5-hydroxy-4-methoxy-2-nitrophenyl)propane-1,2-diol), and compound 5 (3-(3-hydroxy-4-methoxyphenyl)propane1,2-diol), could have occurred through two mechanisms; unimolecular isomerisation of the $\beta$-hydroxyalkoxy radical through a $1,5 \mathrm{H}$-atom shift, or the self/cross $\mathrm{RO}_{2}$ reactions of the $\beta$-hydroxyperoxy radicals through the non-radical pathway. The isomerisation pathway would seem unlikely due to the formation of an alkyl radical on the carbon where the $\mathrm{H}$ atom was abstracted, which could decompose, isomerise, or react with $\mathrm{O}_{2}$, with the latter resulting in the formation of a more oxidised product than observed. Decomposition would result in the formation of a compound with fewer carbon atoms than required, and isomerisation would still result in an alkyl radical. The self/cross reactions of $\beta$-hydroxyperoxy radicals would appear to be the more likely pathway, particularly under low $\mathrm{NO}_{\mathrm{x}}$ conditions. After the formation of a diol on the $\mathrm{HC}$ chain, the further oxidation via hydroxyl radical addition to the ring would result in the formation of the third generation SOA compound, 3-(3hydroxy-4-methoxyphenyl)propane-1,2-diol (compound 5), Fig. $4 \mathrm{a}(\mathrm{G})$ and $\mathrm{b}(\mathrm{D})$. Further addition of $\mathrm{NO}_{2}$ to the ring of compound 5 through the hydrogen atom abstraction pathway leads to the formation of a fourth-generation SOA compound 3-(5-hydroxy-4-methoxy-2-nitrophenyl)propane-1,2-diol (compound 1), Fig. 4a (H) and b (E). A hydroxyl radical can abstract a hydrogen atom from the oxygen-hydrogen bond of the hydroxyl group on the substituted phenol, resulting in the formation of a phenoxy radical and the loss of $\mathrm{H}_{2} \mathrm{O}$ (Forstner et al., 1997; Atkinson, 1994, 2000). The phenoxy radical can then react with $\mathrm{NO}_{2}$ to form a substituted nitrophenol (Atkinson, 1994, 2000; Forstner et al., 1997).

Compounds 2, 3, 4, 6 and 7 contain acid functional groups and less carbon atoms than the original VOC precursor, methyl chavicol. These compounds appear to be later generation SOA species and could have formed through a number of potential mechanisms, such as reactions with ozone (O'Neal and Blumstein, 1973; Orzechowska and Paulson, 2005; Neeb et al., 1996; Calvert et al., 2000), and/or with hydroxyl radicals (Forstner et al., 1997; Gai et al., 2013), although the detailed reaction mechanisms for the formation of organic acids from hydroxyl radicals has not been properly established (Carlton et al., 2009). Compounds 4 and 7 appear to be the further oxidation products of compounds 2 and 6 , respectively, through the addition of a hydroxyl radical to the ring. In addition, compound 3 appears to be the further oxidation product of compound 7 , through a second addition of a hydroxyl radical to the ring. Here we suggest the second addition of the hydroxyl radical to the ring of compound 7 is in the para position to the hydroxyl group, the most resonancestabilised and least sterically hindered position.

\subsection{Atmospheric relevance}

The SOA yields obtained in this study for the photooxidation of methyl chavicol, in $\mathrm{MC}_{\text {low }}(18 \%)$ and $\mathrm{MC}_{\text {high }}$ (29\%) are comparatively lower than the $40 \%$ SOA yield reported previously (Lee et al., 2006b), although there are a number of key differences between the two studies. Lee et al. (2006b) used ammonium sulfate seed (compared to the nucleation-only experiments presented here), which has been shown to increase the SOA yields of aromatic precursors (Kroll et al., 2007; Huang et al., 2013; Lu et al., 2009). In addition, the percentage relative humidity (\% RH) was approximately 5 times greater in the study performed by Lee et al. (2006b). Recent publications have shown that the SOA mass formed from a substituted aromatic compound ( $p$-xylene) increases with increasing \% RH, approximately by a factor of 2 over a $\%$ RH range of $5-75 \%$ (Zhou et al., 2011; Healy et al., 2009). Nevertheless, it is clear the photo-oxidation of methyl chavicol results in significant SOA formation. Recent literature has shown oxygenated biogenic VOCs containing 10 carbon atoms (including eucalyptol, verbenone, linalool) resulted in an SOA yield between 16 to $20 \%$, with the use of neutral (Iinuma et al., 2008; Varutbangkul et al., 2006; Lee et al., 2006b) or acidic (Iinuma et al., 2008) seed. It is difficult to directly compare SOA yields from the oxidation of similar VOC precursors in the literature due to the limitations of using chamberderived data (Camredon et al., 2007). However, reported SOA yields of methyl chavicol were the highest of all oxygenated VOCs investigated (SOA yield 26-40\%) (Lee et al., 2006b; Varutbangkul et al., 2006). Although these experiments are at concentrations higher than the real atmosphere, they suggest that methyl chavicol can act as an important SOA precursor in regions where methyl chavicol emissions are significant, such as downwind from pine forests and oil palm plantations.

Aerosol loadings where methyl chavicol emissions are significant, such as in northern Borneo, have been found to range from $5 \mu \mathrm{g} \mathrm{m}^{-3}$ ( $800 \mathrm{~m}$ above the oil palm plantation) to $100 \mu \mathrm{g} \mathrm{m}^{-3}$ (in a chimney plume of a near-source oil palm processing plant) (MacKenzie et al., 2011). The aerosol loadings formed in these experiments are considerably higher $\left(\mathrm{MC}_{\text {low }} 126\right.$ and $\left.\mathrm{MC}_{\text {high }} 430 \mu \mathrm{g} \mathrm{m}^{-3}\right)$ than the aerosol loadings observed in ambient conditions. It is therefore likely that more compounds are observed in the aerosol phase in this study than would be at atmospherically relevant conditions; due to more higher volatility species partitioning into the aerosol phase at higher mass loadings (Pankow, 1994a, b; Odum et al., 1996). However, the structurally identified compounds were characterised as semi- to low-volatility oxygenated organic aerosol; where at atmospherically relevant conditions a sizable fraction of these compounds would be expected to exist in the aerosol phase (cf. Donahue et al., 2012). 


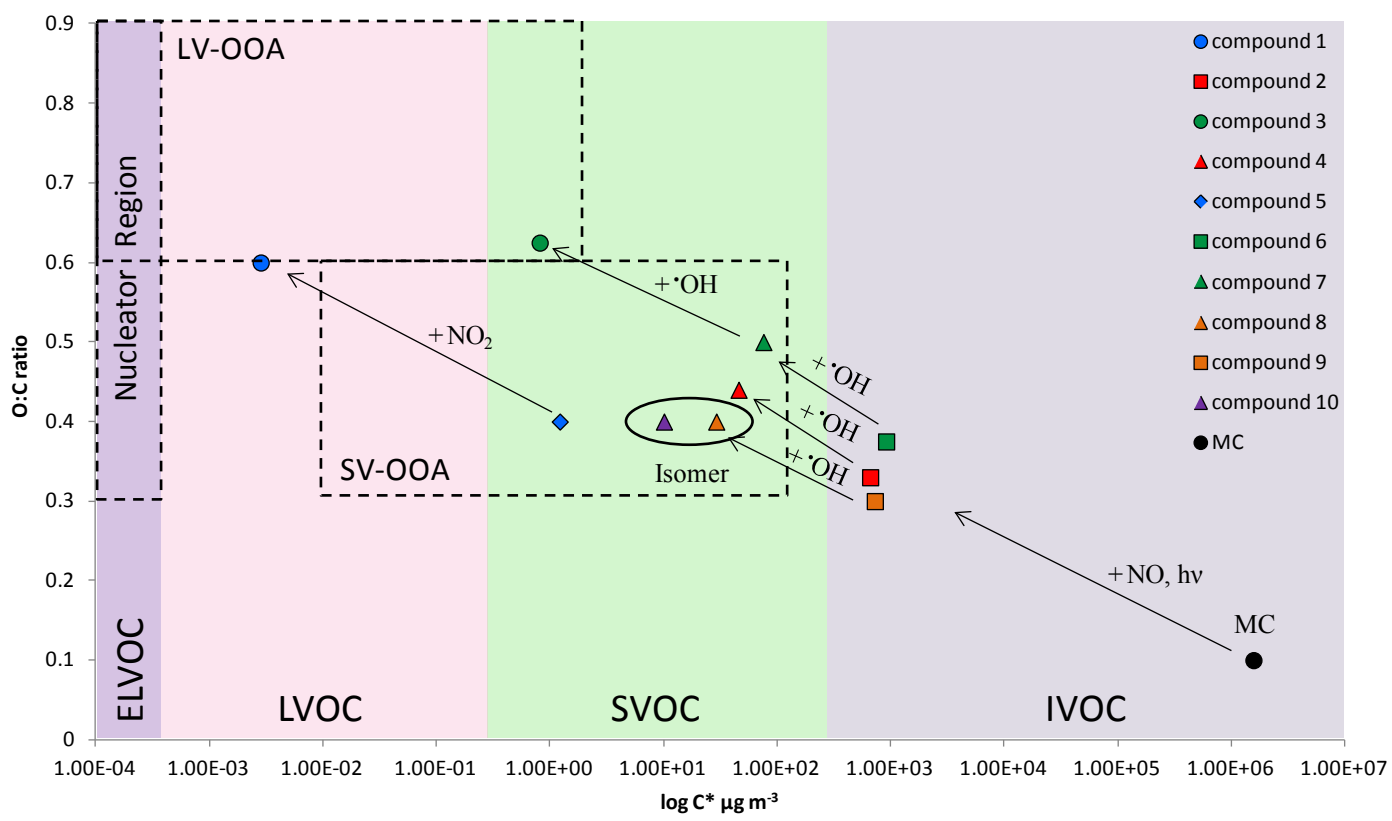

Figure 5. Oxygen to carbon ratio $(\mathrm{O}: \mathrm{C})$ and saturation concentration $\log C^{*}$ (Donahue et al., 2006b) space to show the movement of the identified SOA compounds to lower volatilities upon oxidation in $\mathrm{MC}_{\mathrm{high}}$. Related generations of compounds are shown in the same colour. The change of shape but use of the same colour indicates a change in the SOA compound structure through the reaction with $\cdot \mathrm{OH}$ radicals or $\mathrm{NO}_{2}$. See legend for SOA compound identification and refer to Table 2. O : C vs. $\log C^{*}$ space with associated volatilities have been redrawn from Donahue et al. (2013) and Jimenez et al. (2009).

The SOA compounds identified in this study will be representative of methyl chavicol oxidation products formed in polluted environments (high $\mathrm{NO}_{\mathrm{x}}$ ) and downwind of pollution sources (low $\mathrm{NO}_{\mathrm{x}}$, high $\mathrm{O}_{3}$ ). At the start of the chamber experiments, the high-NO concentrations will be representative of methyl chavicol emissions directly next to a high-NO source, such as a processing plant (MacKenzie et al., 2011). Here, the peroxy radicals (ROO.) will preferentially react with $\mathrm{NO}$, forming alkoxy radicals (RO-) and $\mathrm{NO}_{2}$ (leading to $\mathrm{O}_{3}$ formation). As a relatively low-NO environment in the chamber is entered (i.e. the majority of $\mathrm{NO}$ has been converted to $\mathrm{NO}_{2}$ ), the $\mathrm{RO}_{2}$ radicals will increasingly react with $\mathrm{RO}_{2}$ or (primarily) $\mathrm{HO}_{2}$, instead of NO. The oxidation products formed whilst the NO concentration is relatively low, but the $\mathrm{NO}_{2}$ concentration is near maximum, will be representative of the methyl chavicol oxidation products formed in polluted environments, i.e. agro-industrialised oil palm plantation sites (MacKenzie et al., 2011). As the chamber experiment progresses, the $\mathrm{NO}_{2}$ concentration decreases, approaching zero (as the $\mathrm{NO}_{\mathrm{x}}$ is not replenished in the chamber) and the $\mathrm{O}_{3}$ concentration increases from the photolysis of $\mathrm{NO}_{2}$. This chamber scenario then corresponds to an environment representative of the products formed downwind of an agro-industrialised oil palm plantation, where there is less pollution (low $\mathrm{NO}_{\mathrm{x}}$ ) but $\mathrm{O}_{3}$ is present.

Four compounds with a MW of 122, 136, 150 and $166 \mathrm{~g} \mathrm{~mol}^{-1}$ were observed in the gas phase using PTR-MS and may be attributed to 4-methoxytoluene, 4-methoxybenzaldhyde, 4-methoxybenzene acetaldehyde and (4-methoxyphenyl)acetic acid, respectively, in agreement with Lee et al. (2006b), Spada et al. (2008) and Gai et al. (2013). These compounds are formed as a result of decomposition leading to higher volatility species and are therefore not included in Fig. $4 \mathrm{a}$ and $\mathrm{b}$. The gas phase oxidation mechanisms of these compounds can be observed in Gai et al. (2013). In contrast to Cahill et al. (2006) and Bouvier-Brown et al. (2009) 4methoxybenzaldhyde (MW 136) and 4-methoxybenzene acetaldehyde (MW 150) were not identified in the aerosol phase in this study. Compound vapour pressures were calculated using the UManSysProp website (http://ratty.cas. manchester.ac.uk/informatics/) at $298.15 \mathrm{~K}$, using the Nannoolal vapour pressure and boiling point extrapolation method (Nannoolal et al., 2004, 2008) and the saturation concentration $\left(C^{*}, \mu \mathrm{g} \mathrm{m}^{-3}\right)$ determined (Donahue et al., 2006a). The calculated volatility of these compounds suggests they are intermediate VOCs (4-methoxybenzaldehyde, $C^{*}=4.96 \times 10^{5} \mathrm{\mu g} \mathrm{m}^{-3}$ and 4-methoxybenzene acetaldehyde, $C^{*}=3.02 \times 10^{5} \mu \mathrm{g} \mathrm{m}^{-3}$ ). The use of gas phase scrubbers for organics in the PILS sampler used in this study may indicate that previous ambient observations are due to positive artefacts from gas phase absorption to filters.

The saturation concentration $\left(C^{*}, \mu \mathrm{g} \mathrm{m}^{-3}\right)$ (Donahue et al., 2006a) and $\mathrm{O}: \mathrm{C}$ ratio were determined for all the identified compounds and plotted in a $\mathrm{O}: \mathrm{C}$ vs. $\log C^{*} \mu \mathrm{g} \mathrm{m} \mathrm{m}^{-3}$ volatility basis set space (Donahue et al., 2013; Jimenez et 
al., 2009), as shown in Fig. 5. All of the identified SOA compounds retained the aromatic ring, with $\mathrm{O}: \mathrm{C}$ ratios between 0.30 to 0.63 and $\mathrm{H}: \mathrm{C}$ ratios between 1.00 and 1.40 . The oxidation of methyl chavicol and its early generation products resulted in the formation of low vapour pressure and a high $\mathrm{O}: \mathrm{C}$ ratio species, due to the lack of ring fragmentation. This resulted in the movement of the SOA compounds to lower volatilities and higher $\mathrm{O}: \mathrm{C}$ ratios; thus, functionalisation rather than fragmentation was mainly observed. The majority of the structurally identified SOA species underwent oxidation on the aromatic ring, through the addition of $\cdot \mathrm{OH}$ and/or $\mathrm{NO}_{2}$. The formation of compound 1 (3-(5-hydroxy-4-methoxy-2-nitrophenyl)propane1,2-diol) through the addition of a $\mathrm{NO}_{2}$ group on the aromatic ring resulted in the movement of this species to the low-volatility oxygenated organic aerosol region (LVOOA), and just outside the extremely low-volatility oxygenated organic aerosol (ELVOOA) nucleator region proposed by Donahue et al. (2013). Ring addition appears to be an important pathway, resulting in the formation of low-volatility species with high $\mathrm{O}: \mathrm{C}$ ratios, which may also be important for other aromatic compounds. Only structures for 8 of the 59 compounds detected could be tentatively identified; however, 2 structures were confirmed with authentic standards. Further work is required to characterise the SOA formed from methyl chavicol oxidation at different mixing ratios and with different oxidants $\left(\mathrm{O}_{3}, \mathrm{NO}_{3}\right), \mathrm{NO}_{\mathrm{x}}$ levels, $\mathrm{RHs}$ and seed aerosol compositions.

Acknowledgements. The assistance of scientists at EUPHORE and the York Centre of Excellence in Mass Spectrometry is gratefully acknowledged. This work was supported by EUROCHAMP-2 (TA project E2-2011-04-19-0059). A. R. Rickard acknowledges the support of the National Centre for Atmospheric Science. The York Centre of Excellence in Mass Spectrometry was created thanks to a major capital investment through Science City York, supported by Yorkshire Forward with funds from the Northern Way Initiative. K. L. Pereira acknowledges support of a NERC PhD studentship (NE106026057).

Edited by: Y. Rudich

\section{References}

Adams, R. P.: Identification of essential oil components by gas chromatography/mass spectrometry, 4th Edn., Allured Publishing Corporation, Carol Stream, 2007.

Atkinson, R.: Gas-phase trosposheric chemistry of organic compounds, J. Phys. Chem. Ref. Data, 2, 1-216, 1994.

Atkinson, R.: Gas-phase tropospheric chemistry of volatile organic compounds, 1. Alkanes and alkenes, J. Phys. Chem. Ref. Data, 26, 215-290, 1997a.

Atkinson, R.: Atmospheric reactions of alkoxy and betahydroxyalkoxy radicals, Int. J. Chem. Kinet., 29, 99111, doi:10.1002/(SICI)1097-4601(1997)29:2<99::AIDKIN3>3.0.CO;2-F, 1997b.
Atkinson, R.: Atmospheric chemistry of VOCs and $\mathrm{NO}_{\mathrm{x}}$, Atmos. Environ., 34, 2063-2101, doi:10.1016/S1352-2310(99)00460-4, 2000.

Barazani, O., Cohen, Y., Fait, A., Diminshtein, S., Dudai, N., Ravid, U., Putievsky, E., and Friedman, J.: Chemotypic differentiation in indigenous populations of Foeniculum vulgare var. vulgare in Israel, Biochem. Syst. Ecol., 30, 721-731, doi:10.1016/S03051978(02)00019-4, 2002.

Becker, K.: EUPHORE: Final report to the European commission, Contract \#EV5V-CT92-0059, Bergische Universität Wuppertal, Wuppertal, Germany, 1996.

Bernstein, J. A., Alexis, N., Barnes, C., Bernstein, I. L., Bernstein, J. A., Nel, A., Peden, D., Diaz-Sanchez, D., Tarlo, S. M., and Williams, P. B.: Health effects of air pollution, J. Allergy Clin. Immunol., 114, 1116-1123, doi:10.1016/j.jaci.2004.08.030, 2004.

Bloss, C., Wagner, V., Bonzanini, A., Jenkin, M. E., Wirtz, K., Martin-Reviejo, M., and Pilling, M. J.: Evaluation of detailed aromatic mechanisms (MCMv3 and MCMv3.1) against environmental chamber data, Atmos. Chem. Phys., 5, 623-639, doi:10.5194/acp-5-623-2005, 2005.

Bloss, W. J., Alam, M. S., Rickard, A. R., Hamilton, J. F., Pereira, K. L., Camredon, M., Muñoz, A., Vázquez, M., Alacreu, P., Ródenas, M., and Vera, T.: Atmospheric Chemistry of Methyl Chavicol (Estragole), AGU Fall Meeting, Fall meeting 3 to 7 December 2012, A33L-0313, San Francisco, 2012.

Bouvier-Brown, N. C.: Quantifying reactive biogenic volatile organic compounds: Implications for gas-and particle-phase atmospheric chemistry, ProQuest, University of California, Berkeley, CA, 2008.

Bouvier-Brown, N. C., Goldstein, A. H., Worton, D. R., Matross, D. M., Gilman, J. B., Kuster, W. C., Welsh-Bon, D., Warneke, C., de Gouw, J. A., Cahill, T. M., and Holzinger, R.: Methyl chavicol: characterization of its biogenic emission rate, abundance, and oxidation products in the atmosphere, Atmos. Chem. Phys., 9, 2061-2074, doi:10.5194/acp-9-2061-2009, 2009.

Bursey, M. M.: Influence of steric inhibition of resonance on ion intensities in mass spectra, J. Am. Chem. Soc., 91, 1861-1862, doi:10.1021/ja01035a053, 1969.

Bursey, M. M. and McLafferty, F. W.: Rearrangements and "Flat-Topped Metastable Ions" in the Mass Spectra of Substituted Nitrobenzenes1, J. Am. Chem. Soc., 88, 5023-5025, doi:10.1021/ja00973a047, 1966.

Cahill, T. M., Seaman, V. Y., Charles, M. J., Holzinger, R., and Goldstein, A. H.: Secondary organic aerosols formed from oxidation of biogenic volatile organic compounds in the Sierra Nevada Mountains of California, J. Geophys. Res., 111, D16312, doi:10.1029/2006JD007178, 2006.

Calvert, J. G., Atkinson, R., Kerr, J., Madronich, S., Moortgat, G., Wallington, T. J., and Yarwood, G.: The mechanisms of atmospheric oxidation of the alkenes, Oxford University Press, New York, 2000.

Calvert, J. G., Atkinson, R., Becker, K. H., Kamens, R. M., Seinfeld, J. H., Wallington, T. J., and Yarwood, G.: The mechanisms of atmospheric oxidation of aromatic hydrocarbons, Oxford University Press, New York, 2002. 
Camredon, M., Aumont, B., Lee-Taylor, J., and Madronich, S.: The SOA/VOC/NO $\mathrm{N}_{\mathrm{x}}$ system: an explicit model of secondary organic aerosol formation, Atmos. Chem. Phys., 7, 5599-5610, doi:10.5194/acp-7-5599-2007, 2007.

Carlton, A. G., Wiedinmyer, C., and Kroll, J. H.: A review of Secondary Organic Aerosol (SOA) formation from isoprene, Atmos. Chem. Phys., 9, 4987-5005, doi:10.5194/acp-9-4987-2009, 2009.

Carter, W., Atkinson, R., Winer, A., and Pitts, J.: Evidence for chamber-dependent radical sources: Impact on kinetic computer models for air pollution, Int. J. Chem. Kinet., 13, 735-740, 1981.

Carter, W., Atkinson, R., Winer, A., and Pitts, J.: Experimental investigation of chamber-dependent radical sources, Int. J. Chem. Kinet., 14, 1071-1103, 1982.

Cvetanovic, R.: Chemical kinetic studies of atmospheric interest, 12th International Symposium on Free Radicals, 4-9 January, Laguna Beach, CA, 1976.

Davidson, C. I., Phalen, R. F., and Solomon, P. A.: Airborne particulate matter and human health: A review, Aerosol Sci. Tech., 39, 737-749, 2005

De Vincenzi, M., Silano, M., Maialetti, F., and Scazzocchio, B.: Constituents of aromatic plants: II. Estragole, Fitoterapia, 71, 725-729, 2000.

Donahue, N. M., Robinson, A., Stanier, C., and Pandis, S.: Coupled partitioning, dilution, and chemical aging of semivolatile organics, Environ. Sci. Technol., 40, 2635-2643, 2006 a.

Donahue, N. M., Robinson, A. L., Stanier, C. O., and Pandis, S. N.: Coupled Partitioning, Dilution, and Chemical Aging of Semivolatile Organics, Environmental Sci. Technol., 40, 26352643, doi:10.1021/es052297c, 2006b.

Donahue, N. M., Kroll, J. H., Pandis, S. N., and Robinson, A. L.: A two-dimensional volatility basis set - Part 2: Diagnostics of organic-aerosol evolution, Atmos. Chem. Phys., 12, 615-634, doi:10.5194/acp-12-615-2012, 2012.

Donahue, N. M., Chuang, W., Ortega, I. K., Riipinen, I., Riccobono, F., Schobesberger, S., Dommen, J., Kulmala, M., Worsnop, D., and Vehkamaki, H.: How Do Organic Vapors Contribute to New-Particle Formation?, Faraday Discuss., 165, 1-13, doi:10.1039/c3fd00046j, 2013.

FAOSTAT - Food and Agriculture Organization of the United Nations: http://faostat3.fao.org/faostat-gateway/ (last access: 11 August 2013), 2012.

Fitzherbert, E. B., Struebig, M. J., Morel, A., Danielsen, F., Brühl, C. A., Donald, P. F., and Phalan, B.: How will oil palm expansion affect biodiversity?, Trends Ecol. Evol., 23, 538-545, doi:10.1016/j.tree.2008.06.012, 2008.

Forstner, H. J., Flagan, R. C., and Seinfeld, J. H.: Secondary organic aerosol from the photooxidation of aromatic hydrocarbons: Molecular composition, Environ. Sci. Technol., 31, 1345-1358, 1997.

Fu, X., Zhang, Y., Shi, S., Gao, F., Wen, D., Li, W., Liao, Y., and Liu, H.: Fragmentation study of hexanitrostilbene by ion trap multiple mass spectrometry and analysis by liquid chromatography/mass spectrometry, Rapid Commun. Mass Spectrom., 20, 2906-2914, 2006.
Fuchs, H., Bohn, B., Hofzumahaus, A., Holland, F., Lu, K. D., Nehr, S., Rohrer, F., and Wahner, A.: Detection of $\mathrm{HO}_{2}$ by laserinduced fluorescence: calibration and interferences from $\mathrm{RO}_{2}$ radicals, Atmos. Meas. Tech., 4, 1209-1225, doi:10.5194/amt4-1209-2011, 2011.

Gai, Y., Wang, W., Ge, M., Kjaergaard, H. G., Jørgensen, S., and Du, L.: Methyl chavicol reactions with ozone, $\mathrm{OH}$ and $\mathrm{NO}_{3}$ radicals: Rate constants and gas-phase products, Atmos. Environ., 77, 696-702, doi:10.1016/j.atmosenv.2013.05.041, 2013.

Goldstein, A. H. and Galbally, I. E.: Known and unexplored organic constituents in the earth's atmosphere, Environ. Sci. Technol., 41, 1514-1521, 2007.

Guenther, A., Hewitt, C. N., Erickson, D., Fall, R., Geron, C., Graedel, T., Harley, P., Klinger, L., Lerdau, M., and McKay, W.: A global model of natural volatile organic compound emissions, J. Geophys. Res., 100, 8873-8892, 1995.

Guenther, A., Geron, C., Pierce, T., Lamb, B., Harley, P., and Fall, R.: Natural emissions of non-methane volatile organic compounds, carbon monoxide, and oxides of nitrogen from North America, Atmos. Environ., 34, 2205-2230, 2000.

Hallquist, M., Wenger, J. C., Baltensperger, U., Rudich, Y., Simpson, D., Claeys, M., Dommen, J., Donahue, N. M., George, C., Goldstein, A. H., Hamilton, J. F., Herrmann, H., Hoffmann, T., Inuma, Y., Jang, M., Jenkin, M. E., Jimenez, J. L., Kiendler-Scharr, A., Maenhaut, W., McFiggans, G., Mentel, Th. F., Monod, A., Prévôt, A. S. H., Seinfeld, J. H., Surratt, J. D., Szmigielski, R., and Wildt, J.: The formation, properties and impact of secondary organic aerosol: current and emerging issues, Atmos. Chem. Phys., 9, 5155-5236, doi:10.5194/acp-9-51552009, 2009.

Hayen, H., Jachmann, N., Vogel, M., and Karst, U.: LC-Electron capture APCI-MS for the determination of nitroaromatic compounds, Analyst, 127, 1027-1030, 2002.

Healy, R. M., Temime, B., Kuprovskyte, K., and Wenger, J. C.: Effect of relative humidity on gas/particle partitioning and aerosol mass yield in the photooxidation of p-xylene, Environ. Sci. Technol., 43, 1884-1889, 2009.

Hewitt, C. N., MacKenzie, A. R., Di Carlo, P., Di Marco, C. F., Dorsey, J. R., Evans, M., Fowler, D., Gallagher, M. W., Hopkins, J. R., Jones, C. E., Langford, B., Lee, J. D., Lewis, A. C., Lim, S. F., McQuaid, J., Misztal, P., Moller, S. J., Monks, P. S., Nemitz, E., Oram, D. E., Owen, S. M., Phillips, G. J., Pugh, T. A. M., Pyle, J. A., Reeves, C. E., Ryder, J., Siong, J., Skiba, U., and Stewart, D. J.: Nitrogen management is essential to prevent tropical oil palm plantations from causing groundlevel ozone pollution, P. Natl. Acad. Sci., 106, 18447-18451, doi:10.1073/pnas.0907541106, 2009.

Holčapek, M., Lísa, M., Volná, K., Almonasy, N., and Přikryl, J.: Occurrence of radical molecular ions in atmospheric pressure chemical ionization mass spectra of heterocyclic compounds, J. Mass. Spectrom., 42, 1645-1648, doi:10.1002/jms.1318, 2007.

Holčapek, M., Jirásko, R., and Lísa, M.: Basic rules for the interpretation of atmospheric pressure ionization mass spectra of small molecules, J. Chromatogr. A, 1217, 3908-3921, 2010.

Holzinger, R., Lee, A., Paw, K. T., and Goldstein, U. A. H.: Observations of oxidation products above a forest imply biogenic emissions of very reactive compounds, Atmos. Chem. Phys., 5, 67-75, doi:10.5194/acp-5-67-2005, 2005. 
Holzinger, R., Kasper-Giebl, A., Staudinger, M., Schauer, G., and Röckmann, T.: Analysis of the chemical composition of organic aerosol at the Mt. Sonnblick observatory using a novel high mass resolution thermal-desorption proton-transfer-reaction mass-spectrometer (hr-TD-PTR-MS), Atmos. Chem. Phys., 10, 10111-10128, doi:10.5194/acp-10-10111-2010, 2010.

Howard, J. A. and Ingold, K. U.: Self-reaction of sec-butylperoxy radicals. Confirmation of the Russell mechanism, J. Am. Chem. Soc., 90, 1056-1058, doi:10.1021/ja01006a037, 1968.

Huang, M., Hao, L., Gu, X., Hu, C., Zhao, W., Wang, Z., Fang, L., and Zhang, W.: Effects of inorganic seed aerosols on the growth and chemical composition of secondary organic aerosol formed from $\mathrm{OH}$-initiated oxidation of toluene, J. Atmos. Chem., 70, 151-164, doi:10.1007/s10874-013-9262-9, 2013.

Iinuma, Y., Böge, O., Keywood, M., Gnauk, T., and Herrmann, H.: Diaterebic Acid Acetate and Diaterpenylic Acid Acetate: Atmospheric Tracers for Secondary Organic Aerosol Formation from 1,8-Cineole Oxidation, Environ. Sci. Technol., 43, 280285, doi:10.1021/es802141v, 2008.

Jimenez, J. L., Canagaratna, M. R., Donahue, N. M., Prevot, A. S. H., Zhang, Q., Kroll, J. H., DeCarlo, P. F., Allan, J. D., Coe, H., Ng, N. L., Aiken, A. C., Docherty, K. S., Ulbrich, I. M., Grieshop, A. P., Robinson, A. L., Duplissy, J., Smith, J. D., Wilson, K. R., Lanz, V. A., Hueglin, C., Sun, Y. L., Tian, J., Laaksonen, A., Raatikainen, T., Rautiainen, J., Vaattovaara, P., Ehn, M., Kulmala, M., Tomlinson, J. M., Collins, D. R., Cubison, M. J., E., Dunlea, J., Huffman, J. A., Onasch, T. B., Alfarra, M. R., Williams, P. I., Bower, K., Kondo, Y., Schneider, J., Drewnick, F., Borrmann, S., Weimer, S., Demerjian, K., Salcedo, D., Cottrell, L., Griffin, R., Takami, A., Miyoshi, T., Hatakeyama, S., Shimono, A., Sun, J. Y., Zhang, Y. M., Dzepina, K., Kimmel, J. R., Sueper, D., Jayne, J. T., Herndon, S. C., Trimborn, A. M., Williams, L. R., Wood, E. C., Middlebrook, A. M., Kolb, C. E., Baltensperger, U., and Worsnop, D. R.: Evolution of Organic Aerosols in the Atmosphere, Science, 326, 1525-1529, doi:10.1126/science.1180353, 2009.

Kebarle, P. and Verkerk, U. H.: Electrospray: From ions in solution to ions in the gas phase, what we know now, Mass. Spectrom. Rev., 28, 898-917, doi:10.1002/mas.20247, 2009.

Khan, S., Zhang, Q., and Broadbelt, L.: Automated mechanism generation, Part 1: mechanism development and rate constant estimation for VOC chemistry in the atmosphere, J. Atmos. Chem., 63, 125-156, doi:10.1007/s10874-010-9164-z, 2009.

Kind, T. and Fiehn, O.: Metabolomic database annotations via query of elemental compositions: mass accuracy is insufficient even at less than $1 \mathrm{ppm}$, BMC Bioinformatics, 1, 1-10, doi:10.1186/1471-2105-7-234, 2006.

Klotz, B., Sørensen, S., Barnes, I., Becker, K. H., Etzkorn, T., Volkamer, R., Platt, U., Wirtz, K., and Martín-Reviejo, M.: Atmospheric oxidation of toluene in a large-volume outdoor photoreactor: In situ determination of ring-retaining product yields, J. Phys. Chem. A, 102, 10289-10299, 1998.

Kroll, J. H. and Seinfeld, J. H.: Chemistry of secondary organic aerosol: Formation and evolution of low-volatility organics in the atmosphere, Atmos. Environ., 42, 3593-3624, doi:10.1016/j.atmosenv.2008.01.003, 2008.
Kroll, J. H., Chan, A. W. H., Ng, N. L., Flagan, R. C., and Seinfeld, J. H.: Reactions of Semivolatile Organics and Their Effects on Secondary Organic Aerosol Formation, Environ. Sci. Technol., 41, 3545-3550, doi:10.1021/es062059x, 2007.

Lee, A., Goldstein, A. H., Keywood, M. D., Gao, S., Varutbangkul, V., Bahreini, R., Ng, N. L., Flagan, R. C., and Seinfeld, J. H.: Gas-phase products and secondary aerosol yields from the ozonolysis of ten different terpenes, J. Geophys. Res., 111, D07302, doi:10.1029/2005JD006437, 2006a.

Lee, A., Goldstein, A. H., Kroll, J. H., Ng, N. L., Varutbangkul, V., Flagan, R. C., and Seinfeld, J. H.: Gas-phase products and secondary aerosol yields from the photooxidation of 16 different terpenes, J. Geophys. Res., 111, D17305, doi:10.1029/2006JD007050, 2006b.

Lu, Z., Hao, J., Takekawa, H., Hu, L., and Li, J.: Effect of high concentrations of inorganic seed aerosols on secondary organic aerosol formation in the $\mathrm{m}$-xylene/NOx photooxidation system, Atmos. Environ., 43, 897-904, 2009.

MacKenzie, A. R., Langford, B., Pugh, T. A. M., Robinson, N., Misztal, P. K., Heard, D. E., Lee, J. D., Lewis, A. C., Jones, C. E., Hopkins, J. R., Phillips, G., Monks, P. S., Karunaharan, A., Hornsby, K. E., Nicolas-Perea, V., Coe, H., Gabey, A. M., Gallagher, M. W., Whalley, L. K., Edwards, P. M., Evans, M. J., Stone, D., Ingham, T., Commane, R., Furneaux, K. L., McQuaid, J. B., Nemitz, E., Seng, Y. K., Fowler, D., Pyle, J. A., and Hewitt, C. N.: The atmospheric chemistry of trace gases and particulate matter emitted by different land uses in Borneo, Philos. T. Roy. Soc. B, 366, 3177-3195, doi:10.1098/rstb.2011.0053, 2011.

Madronich, S. and Calvert, J. G.: Permutation reactions of organic peroxy radicals in the troposphere, J. Geophys. Res.-Atmos., 95, 5697-5715, doi:10.1029/JD095iD05p05697, 1990.

March, J.: Advanced organic chemistry: reactions, mechanisms, and structure, John Wiley \& Sons, New York, 1992.

Mirov, N. T.: Composition of Gum Turpentines of Pines, Technical Bulletin No. 1239, USDA forest service, 158 pp., 1961.

Misztal, P. K., Owen, S. M., Guenther, A. B., Rasmussen, R., Geron, C., Harley, P., Phillips, G. J., Ryan, A., Edwards, D. P., Hewitt, C. N., Nemitz, E., Siong, J., Heal, M. R., and Cape, J. N.: Large estragole fluxes from oil palms in Borneo, Atmos. Chem. Phys., 10, 4343-4358, doi:10.5194/acp-10-4343-2010, 2010.

MPOB - Offical Portal Of Malaysian Palm Oil Board: http://bepi. mpob.gov.my/ (last access: 11 April 2013), 2012.

Nannoolal, Y., Rarey, J., Ramjugernath, D., and Cordes, W.: Estimation of pure component properties: Part 1. Estimation of the normal boiling point of non-electrolyte organic compounds via group contributions and group interactions, Fluid Phase Equil., 226, 45-63, doi:10.1016/j.fluid.2004.09.001, 2004.

Nannoolal, Y., Rarey, J., and Ramjugernath, D.: Estimation of pure component properties: Part 3. Estimation of the vapor pressure of non-electrolyte organic compounds via group contributions and group interactions, Fluid Phase Equil., 269, 117-133, 2008.

Neeb, P., Horie, O., and Moortgat, G. K.: Gas-phase ozonolysis of ethene in the presence of hydroxylic compounds, Int. J. Chem. Kinet., 28, 721-730, doi:10.1002/(SICI)10974601(1996)28:10<721::AID-KIN2>3.0.CO;2-P, 1996.

Odum, J. R., Hoffmann, T., Bowman, F., Collins, D., Flagan, R. C., and Seinfeld, J. H.: Gas/Particle Partitioning and Secondary Organic Aerosol Yields, Environ. Sci. Technol., 30, 2580-2585, doi:10.1021/es950943, 1996. 
O’Neal, H. E. and Blumstein, C.: A new mechanism for gas phase ozone-olefin reactions, Int. J. Chem. Kinet., 5, 397-413, 1973.

Orlando, J. J., Tyndall, G. S., and Wallington, T. J.: The atmospheric chemistry of alkoxy radicals, Chem. Rev., 103, 46574690, 2003.

Orsini, D. A., Ma, Y., Sullivan, A., Sierau, B., Baumann, K., and Weber, R. J.: Refinements to the particle-into-liquid sampler (PILS) for ground and airborne measurements of water soluble aerosol composition, Atmos. Environ., 37, 1243-1259, 2003.

Orzechowska, G. E. and Paulson, S. E.: Photochemical Sources of Organic Acids, 1. Reaction of Ozone with Isoprene, Propene, and 2-Butenes under Dry and Humid Conditions Using SPME, J. Phys. Chem. A, 109, 5358-5365, doi:10.1021/jp050166s, 2005.

Pankow, J. F.: An absorption model of the gas/aerosol partitioning involved in the formation of secondary organic aerosol, Atmos. Environ., 28, 189-193, 1994a.

Pankow, J. F.: An absorption model of gas/particle partitioning of organic compounds in the atmosphere, Atmos. Environ., 28, 185-188, 1994b.

Peeters, J., Boullart, W., Pultau, V., Vandenberk, S., and Vereecken, L.: Structure-Activity Relationship for the Addition of $\mathrm{OH}$ to (Poly)alkenes:? Site-Specific and Total Rate Constants, J. Phys. Chem. A, 111, 1618-1631, doi:10.1021/jp066973o, 2007.

Pellegrin, V.: Molecular formulas of organic compounds: the nitrogen rule and degree of unsaturation, J. Chem. Educ., 60, 626, doi:10.1021/ed060p626, 1983.

Pitts, J. N., Biermann, H. W., Atkinson, R., and Winer, A. M.: Atmospheric implications of simultaneous nighttime measurements of $\mathrm{NO}_{3}$ radicals and HONO, Geophys. Res. Lett., 11, 557-560, doi:10.1029/GL011i005p00557, 1984.

Pöschl, U.: Atmospheric Aerosols: Composition, Transformation, Climate and Health Effects, Angew. Chem. Int. Edit., 44, 7520 7540, doi:10.1002/anie.200501122, 2005.

Rickard, A. R., Wyche, K. P., Metzger, A., Monks, P. S., Ellis, A. M., Dommen, J., Baltensperger, U., Jenkin, M. E., and Pilling, M. J.: Gas phase precursors to anthropogenic secondary organic aerosol: Using the Master Chemical Mechanism to probe detailed observations of 1,3,5trimethylbenzene photo-oxidation, Atmos. Environ., 44, 54235433, doi:10.1016/j.atmosenv.2009.09.043, 2010.

Sakamaki, F., Hatakeyama, S., and Akimoto, H.: Formation of nitrous acid and nitric oxide in the heterogeneous dark reaction of nitrogen dioxide and water vapor in a smog chamber, Int. J. Chem. Kinet., 15, 1013-1029, doi:10.1002/kin.550151006, 1983.

Schade, G. W. and Goldstein, A. H.: Fluxes of oxygenated volatile organic compounds from a ponderosa pine plantation, J. Geophys. Res., 106, 3111-3123, 2001.

Schmidt, A.-C., Herzschuh, R., Matysik, F.-M., and Engewald, W.: Investigation of the ionisation and fragmentation behaviour of different nitroaromatic compounds occurring as polar metabolites of explosives using electrospray ionisation tandem mass spectrometry, Rapid Commun. Mass. Spectrom., 20, 2293-2302, doi:10.1002/rcm.2591, 2006.

Singh, H., Chen, Y., Tabazadeh, A., Fukui, Y., Bey, I., Yantosca, R., Jacob, D., Arnold, F., Wohlfrom, K., Atlas, E., Flocke, F., Blake, D., Blake, N., Heikes, B., Snow, J., Talbot, R., Gregory, G., Sachse, G., Vay, S., and Kondo, Y.: Distribution and fate of selected oxygenated organic species in the troposphere and lower stratosphere over the Atlantic, J. Geophys. Res.-Atmos., 105, 3795-3805, doi:10.1029/1999jd900779, 2000.

Solomon, S., Qin, D., Manning, M., Chen, Z., Marquis, M., Averyt, K., Tignor, M., and Miller, H.: Climate change 2007: the physical science basis: working Group I contribution to the fourth assessment report of the IPCC, Cambridge University Press, Cambridge, 2007.

Song, C., Na, K., and Cocker, D. R.: Impact of the Hydrocarbon to $\mathrm{NO}_{\mathrm{x}}$ Ratio on Secondary Organic Aerosol Formation, Environ. Sci. Technol., 39, 3143-3149, doi:10.1021/es0493244, 2005.

Southwell, I. A., Russell, M. F., Smith, R. L., and Vinnicombe, A.: Ochrosperma lineare, a new source of methyl chavicol, J. Essent. Oil Res., 15, 329-330, 2003.

Spada, N., Fujii, E., and Cahill, T. M.: Diurnal Cycles of Acrolein and Other Small Aldehydes in Regions Impacted by Vehicle Emissions, Environ. Sci. Technol., 42, 7084-7090, doi:10.1021/es801656e, 2008.

Steiner, A. L., Cohen, R. C., Harley, R. A., Tonse, S., Millet, D. B., Schade, G. W., and Goldstein, A. H.: VOC reactivity in central California: comparing an air quality model to ground-based measurements, Atmos. Chem. Phys., 8, 351-368, doi:10.5194/acp-8351-2008, 2008.

Stockwell, W. R., Middleton, P., Chang, J. S., and Tang, X.: The second generation regional acid deposition model chemical mechanism for regional air quality modeling, J. Geophys. Res., 95, 16343-16367, 1990.

Svensson, R., Ljungström, E., and Lindqvist, O.: Kinetics of the reaction between nitrogen dioxide and water vapour, Atmos. Environ., 21, 1529-1539, 1987.

Taipale, R., Rantala, P., Kajos, M., Patokoski, J., Ruuskanen, T., Aalto, J., Kolari, P., Bäck, J., Hari, P., Kulmala, M., and Rinne, J.: Oxygenated VOC and monoterpene emissions from a boreal coniferous forest, EGU General Assembly Conference Abstracts, 9735, 2012.

USDA - United States Department of Agriculture: Global Crop Production Analysis, http://www.pecad.fas.usda.gov, last access: 4 November 2013.

Varutbangkul, V., Brechtel, F. J., Bahreini, R., Ng, N. L., Keywood, M. D., Kroll, J. H., Flagan, R. C., Seinfeld, J. H., Lee, A., and Goldstein, A. H.: Hygroscopicity of secondary organic aerosols formed by oxidation of cycloalkenes, monoterpenes, sesquiterpenes, and related compounds, Atmos. Chem. Phys., 6, 23672388, doi:10.5194/acp-6-2367-2006, 2006.

Werker, E., Putievsky, E., Ravid, U., Dudai, N., and Katzir, I.: Glandular Hairs, Secretory Cavities, and the Essential Oil in the Leaves of Tarragon (Artemisia dracunculus L.), J. Herb. Spice. Med. Plants, 2, 19-32, 1994.

Wiedinmyer, C., Guenther, A., Harley, P., Hewitt, N., Geron, C., Artaxo, P., Steinbrecher, R., and Rasmussen, R.: Global Organic Emissions from Vegetation, in: Emissions of Atmospheric Trace Compounds, Advances in Global Change Research, edited by: Granier, C., Artaxo, P., and Reeves, C., Springer Netherlands, 115-170, 2004.

Yinon, J., McClellan, J. E., and Yost, R. A.: Electrospray ionization tandem mass spectrometry collision-induced dissociation study of explosives in an ion trap mass spectrometer, Rapid Commun. Mass Spectrom., 11, 1961-1970, doi:10.1002/(SICI)10970231(199712)11:18<1961::AID-RCM99>3.0.CO;2-K, 1997. 
Zhao, X. and Yinon, J.: Identification of nitrate ester explosives by liquid chromatography-electrospray ionization and atmospheric pressure chemical ionization mass spectrometry, J. Chromatogr. A, 977, 59-68, doi:10.1016/S0021-9673(02)01349-3, 2002.

Zhou, Y., Zhang, H., Parikh, H. M., Chen, E. H., Rattanavaraha, W., Rosen, E. P., Wang, W., and Kamens, R. M.: Secondary organic aerosol formation from xylenes and mixtures of toluene and xylenes in an atmospheric urban hydrocarbon mixture: Water and particle seed effects (II), Atmos. Environ., 45, 3882-3890, doi:10.1016/j.atmosenv.2010.12.048, 2011.
Ziemann, P. J. and Atkinson, R.: Kinetics, products, and mechanisms of secondary organic aerosol formation, Chem. Soc. Rev., 41, 6582-6605, doi:10.1039/c2cs35122f, 2012.

Zimmerman, P. R.: Testing of hydrocarbon emissions from vegetation, leaf litter and aquatic surfaces, and development of a methodology for compiling biogenic emission inventories [Final Report], Washington State University Pullman, Washington, 1979. 